\title{
WATER-LAID VOLCANIC ROCKS OF EARLY UPPER CRETACEOUS AGE IN SOUTH- WESTERN ARKANSAS, SOUTHEASTERN OKLAHOMA, AND NORTHEASTERN TEXAS
}

\author{
By Clarence S. Ross, Hugh D. Miser, and Lloyd W. Stephenson
}

\section{INTRODUCTION}

Very few persons associate volcanoes with the flat land of the Gulf Coastal Plain of southwestern Arkansas, but for a number' of years geologists have known that the "roots" of old volcanoes were present near Murfreesboro, in Pike County. They found here not only the rocks that once composed the craters of these volcanoes, but also the decomposed material filling their necks, which carries diamonds and is almost identical with the diamond-bearing earth of the great Kimberley mine of South Africa. Much of the material ejected by these volcanoes was in the form of volcanic ash, sand, and lapilli, which were thrown out by violent explosions and then widely distributed by wind and water.

The present paper deals with these and other volcanoes in Arkansas and with recent discoveries of material that was ejected from them. From the character of this material it has been possible to determine the geologic period in which the explosions occurred, the localities in Arkansas whence the material came, and the agencies by which it was distributed.

\section{DISCOVERY OF ROCKS OF VOLCANIC ORIGIN IN THE WOODBINE AND TOKIO FORMATIONS}

The igneous rocks of Arkansas were for many years believed to have been formed near the end of Cretaceous time. ${ }^{1}$ Later evidence placed their time of intrusion between the Comanche (Lower Cretaceous) and Gulf (Upper Cretaceous) epochs. ${ }^{2}$ The occurrence in the basal Gulf rocks in Arkansas of water-laid materials that have been derived from igneous rocks has been described by several geologists. ${ }^{3}$ Recently discovered evidence indicates that volcanic eruptions accompanied by violent explosions took place near

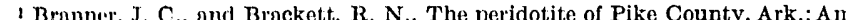
Jour. Scl., 3d ser., vol. 38, pp. 50-59, 1889. Williams, J. F., The igneous rocks of Arkansas: Arkansas Geol. Survey Ann. Rept. for 1890, vol. 2, p. 3, 1891.

2 Glenn, I. C., Arkansas diamond-bearing peridotite (abstract): Geol. Soc. America Bull., vol. 23, p. 726, 1912. Miser, H. D., New areas of diamond-bearing peridotite in Arkansas: U. S. Ceol. Survey Bull. 540, pp. 541-545, 1914.

s Sterrett, 1). B., [Dinmonds in] Arkansas: U. S. Geol. Survey Mineral Resources for 1909, pt. 2, pp. 757-759, 1910. Miser, H. D., op. cit. Miser, H. D., and Purdue, A. H. Gravel deposits of the Caddo Gap and De Queen quadrangles, Ark.: U. S. Geol. Survey 13ull. 690, pp. 22-24, 1918; Miser, H. D., and Ross, C. S., Diamondbenring peridotite in Pike County, Ark.: U. S. Geol. Survey Bull. 735, pp. 291-292, 1023.
Murfreesboro, Ark., early in Gulf time. ${ }^{4}$ The diamond deposits near Murfreesboro occur in the necks of the Cretaceous volcanoes. Yet the discovery of unquestionable volcanic ash and tuff in the Gulf series of southwestern Arkansas was not made until 1923. This discovery has led to the conclusion that much if not all of the water-laid igneous material previously found in the rocks of Gulf age was originally fragmental material that was ejected from volcanic vents.

The volcanic material was identified by Clarence $\mathrm{S}$. Ross in the spring of 1923 during the examination of specimens submitted to the United States Geological Survey by J. N. Garner, of Nashville, Ark. In October, 1923, Miser studied deposits of volcanic material in the Gulf series of southeastern Oklahoma; in November and December, 1923, Ross and Miser made a field investigation of similar deposits in Arkansas; in 1924-1926 L. W. Stephenson studied them in Red River, Lamar, and Fannin Counties in northeastern Texas; in 1925 Miser, Stephenson, and C. H. Dane visited many exposures of the volcanic material in Arkansas, and la ter in 1926 they visited several exposures of it in northeastern Texas.

To Mr. Dane the authors of the present report extend their thanks for his cooperation and assistance both in the field and in the office. To Mr. J. N. Garner they wish to express their sincere appreciation of his cooperation in the field. He personally guided them to exposures of volcanic rocks in Arkansas that he had discovered both before and after he had sent the first specimens to the Geological Survey for identification.

In Arkansas and Oklahoma volcanic rocks of Cretaceous age are so far as known confined to the Woodbine and Tokio formations, but in Texas they are found in the Woodbine sand, Eagle Ford clay, Austin chalk, Taylor marl, and Navarro formation. The Woodbine formation is the basal formation of the Gulf series in southwestern Arkansas, southeastern Oklahoma, and northeastern Texas. In Arkansas and in McCurtain County, Okla., it forms the lower part

4 Miser, H. D., and Ross, C. S., op. cit., pp. 310-312; Econ. Geology, vol. 17, pp. 662-674, 1922; Smithsonian Inst. Ann. Rept. for 1923, pp. 261-272, 1925. Mitchell, G. J., Diamond deposits in Arkansas: Ing. and Min. Jour.-Press, vol. 116, pp. 285-287, 1923. 
of the "Bingen sand" of Veatch, and the Tokio formation is the upper part of the "Bingen." In Arkansas and Oklahoma the Gulf series is separated from the Comanche series by a marked unconformity, and in places in Arkansas the Gulf series rests upon the truncated edges of steeply dipping Paleozoic rocks.

A short preliminary paper on the volcanic rocks in the "Bingen formation" of Arkansas and Oklahoma was recently published ${ }^{5}$ and a brief description of the igneous rocks in the De Queen and Caddo Gap quadrangles, Arkansas and Oklahoma, is given in a report now in press. ${ }^{6}$

\section{DISTRIBUTION OF THE VOLCANIC ROCKS}

The volcanic rocks here described are exposed in an east-west belt of country about 150 miles long that lies near the northern margin of the Gulf Coastal Plain, in Texas, Oklahoma, and Arkansas. The exposures in Arkansas and in McCurtain County, Okla., occur in a strip of high land lying only a few miles south of the north boundary of the Coastal Plain. This strip is a southward-sloping cuesta to which Veatch ${ }^{7}$ has applied the name " Lockesburg," from Lockesburg, Sevier County, Ark. (Veatch used the term "wold" instead of "cuesta," but of these two terms cuesta is in more general. use at present.) The Lockesburg cuesta owes its form and altitude to the resistant character of the southward-dipping beds of gravel, tuff, and sand of the Woodbine and Tokio formations, and it is in general coextensive with the outcrops of these formations as shown on Plate 20. It ranges in width from several to many miles and extends from a point near Delight, Ark., west by south across Pike, Hempstead, Howard, Sevier, and Little River Counties into Oklahoma, where it descends into the bottom lands of Red River west of Idabel, McCurtain County. Within this distance of about 100 miles the cuesta is not continuous but is trenched by the wide alluvial valleys of Little, Cossatot, Saline, and Little Missouri Rivers, which run in a general southeasterly direction, and by the valleys of the small southward-flowing streams between the wide valleys. Owing to the extensive dissection of the cuesta by streams, its surface is rolling to hilly, and there are no large tracts of level country.

The north edge of the cuesta culminates at 600 to 700 feet above sea level, and its northward-facing escarpment is conspicuous, especially in Arkansas, where it rises 100 to 200 feet above the land at its foot.

\footnotetext{
- Miser, H. D., and Ross, C.S., Volcanic rocks in the Upper Cretaceous of southwestern Arkansas and southeastern Oklahoma: Am. Jour. Sci., 5th ser., vol. 9, pp. 113-126, 1925.

- Miser, H. D., and Purdue, A. H., Geology of the De Queen and Caddo Gap quadrangles, Arkansas and Oklahoma: U.S. Geol. Survey Bull. 808, pp. 99-115, 1929.

i Veatch, A. C., Geology and underground water resources of northern Louisiana and southern Arkansas; U, S, Geol. Survey Prof, Paper 46, pp. 14-15, 1906.
}

The country that is underlain by the volcanic rocks of the Woodbine formation is known as "red-land" country and lies along the northern edge of the Lockesburg cuesta. (See pl. 18, A). On it in Arkansas are situated Highland, Corinth, Centerpoint, Horatio, and Cerro Gordo; in Oklahoma, Jadie, Goodwater, Odell, Shults, and Idabel.

The red-land country received its name from the prevailing bright-red color of its clayey soil and subsoil. In spite of its poor appearance the soil produces good crops, especially of peaches and other fruits. The red clay is derived by weathering from volcanic. tuff and owes its fertility to the potash and other mineral ingredients supplied by the tuff.

In northeastern Texas the rocks containing the volcanic material occur in the northern parts of Red. River and Lamar Counties, in a belt having a maximum. width of 5 miles, and in the northwestern part of Fannin County. The Woodbine sand, of which these rocks. are a part, does not form a cuesta here, for the rocks. have been planed off by the terrace-forming processes. operating in the valley of Red River. Most of the. exposures occur in bluffs along Red River beneath a covering of terrace materials or along the sides of tributary valleys whose streams have cut down through the terrace covering.

\section{ROCKS ASSOCIATED WITH THE VOLCANIC MATERIAL,}

\section{GENERAL FEATURES}

Most of the rocks in which the volcanic material is exposed are sedimentary, but some are of igneous origin. The igneous rocks include the four bodies of diamondbearing peridotite near Murfreesboro, Ark.; a dike of ouachitite of possible Cretaceous age 7 miles east of Gillham, Ark., ${ }^{8}$ a diorite sill of Ordovician (?) age 4 miles north of Glover, in northern McCurtain County, Okla. ${ }^{9}$; quartz-orthoclase pegmatites of Carboniferous. age, also in northern McCurtain County ${ }^{9}$; and granite of pre-Cambrian age on the west border of the mapped area (pl. 20) southwest of Atoka, Okla. Beds of volcanic ash and tuff found a short distance north of the Coastal Plain are of Silurian, ${ }^{10}$ Devonian, ${ }^{11}$ and Carboniferous age. ${ }^{12}$

The sedimentary rocks in the country adjoining the Coastal Plain on the north are of Paleozoic age, ranging from Cambrian to Carboniferous, though thin. beds of Quaternary gravel and alluvium are found in places, especially along the streams. (See pl. 20.)

\footnotetext{
8 Mitchell, G. J., Antimony in southwestern Arkansas: Eng. and Min. Jour.Press, vol. 114, pp. 455-456, 1922; also letter dated Sept. 7, 1923.

- Honess, C. W., Geology of the southern Ouachita Mountains of Oklahoma: Oklahoma Geol. Survey Bull. 32, pp. 39-40, 48-49, 64-66, 210-212, 1923.

to Honess, C. W., op. cit., pp. 107-109.

"Idem, pp. 121-139.

${ }_{12}$ Miser, H. D., Mississippian tuff in the Ouachita Mountain region [abstract): Geol. Soc. America Bull. vol. 31, pp. 125-126, 1920 . Honess, C. W., The Stanley shale: Am. Jour. Sci., 5th ser., vol. 1, pp. 63-80, 1921; Oklahoma Geol. Survey Bull. 32, pp. 179-202, 1923
} 
The Paleozoic rocks consist mainly of shale, sandstone, limestone, novaculite, and chert and have a total thickness in west-central Arkansas and southeastern Oklahoma of about 25,000 feet. They were compressed into close westward-trending folds and were broken by many faults near the end of Pennsylvanian time, so that the dips are various but generally at high angles.
The sedimentary rocks of the part of the Coastal Plain in which the volcanic rocks here described occur are of Comanche (Lower Cretaceous), Gulf (Upper Cretaceous), and Quaternary age. They have been grouped into several formations, but only the Woodbine, Eagle Ford, and Tokio formations, which contain the volcanic deposits, are here briefly described. (See fig. 16.)

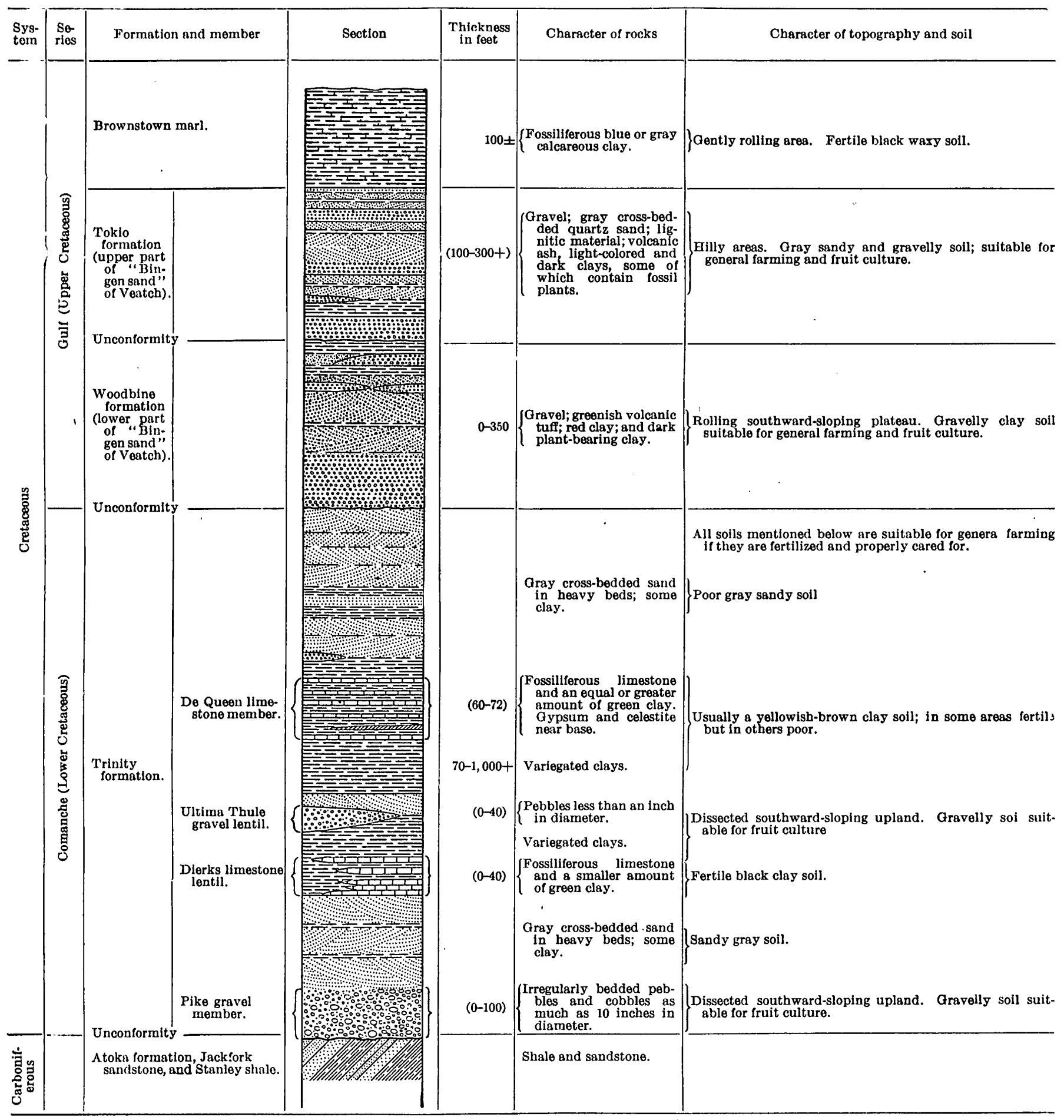

Figure 16.-Generalized section of the oldest Cretaceous rocks exposed in Howard, Pike, and Sevier Counties, Ark. 
Stratigraphic relations of Woodbine and Tokio formations in northeastern Texas, southeastern Oklahoma, and southwestern Arkansas to adjacent formations of Cretaceous age

[For a graphic representation of relations of some of the rocks see section on pl. 20]

\begin{tabular}{|c|c|c|c|}
\hline Northeastern Texas & \multicolumn{2}{|c|}{ Southeastern Oklahoma } & Southwestern Arkansas \\
\hline Brownstown marl. & \multicolumn{2}{|c|}{$\begin{array}{l}\text { Brownstown marl. Present in McCurtain Coun- } \\
\text { ty but not exposed. }\end{array}$} & Brownstown marl (restricted). \\
\hline Blossom sand. & \multirow{2}{*}{\multicolumn{2}{|c|}{$\begin{array}{l}\text { Tokio formation. Present in McCurtain County. } \\
\text {-Unconformity? }\end{array}$}} & \\
\hline Bonham clay. & & & \\
\hline $\begin{array}{l}\text { Ector tongue of Austin chalk; basal } \\
\text { part is shaly clay and sand with "fish- } \\
\text { bed conglomerate" at base. Thins } \\
\text { out toward northeast in Fannin } \\
\text { County. }\end{array}$ & \multicolumn{2}{|l|}{ Not present. } & Not present. \\
\hline Unconformity- & & & \\
\hline $\begin{array}{l}\text { Eagle Ford clay. Thins out toward east } \\
\text { in Lamar and Red River Counties. }\end{array}$ & \multicolumn{2}{|c|}{$\begin{array}{l}\text { Eagle Ford shale present only in Bryan County. } \\
\text {-Unconformity }\end{array}$} & Not present. \\
\hline Woodbine sand. ${ }^{a}$ & \multirow{3}{*}{\multicolumn{2}{|c|}{ 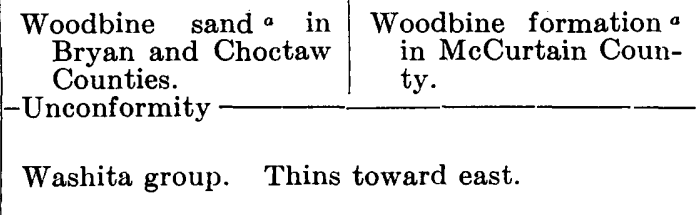 }} & \multirow{3}{*}{$\begin{array}{l}\text { Woodbine formation. }{ }^{a} \text { Thins out } \\
\text { toward east. } \\
\text { - Unconformity- } \\
\begin{array}{l}\text { Washita group. Thins out toward } \\
\text { east. }\end{array}\end{array}$} \\
\hline Unconformity & & & \\
\hline Washita group. & & & \\
\hline Fredericksburg group. & \multicolumn{2}{|l|}{ Goodland limestone. } & $\begin{array}{l}\text { Goodland limestone. Thins out to- } \\
\text { ward east. }\end{array}$ \\
\hline Trinity sand. & \multicolumn{2}{|c|}{$\begin{array}{l}\text { Trinity sand. Thins toward west by overlap of } \\
\text { younger beds of formation over older beds of } \\
\text { formation. }\end{array}$} & $\begin{array}{l}\text { Trinity formation. Thins out toward } \\
\text { east owing to unconformity at base } \\
\text { of Woodbine and Tokio formations. }\end{array}$ \\
\hline
\end{tabular}

- Contains water-laid volcanic rocks.

\section{WOODBINE FORMATION}

The Woodbine formation of the Gulf series (Upper Cretaceous) received its name from the village of Woodbine, in Cooke County, Tex. The formation consists mainly of quartz sand in northeastern Texas and in Bryan and Choctaw Counties, Okla., where it is appropriately called the Woodbine sand. Water-laid volcanic material is present in the Woodbine but increases in quantity toward the east in Texas, Oklahoma, and Arkansas and comprises a large part of the formation in McCurtain County, Okla., and in southwestern Arkansas, where the term formation is more suitable than the term sand. In Arkansas the Woodbine comprises the lower part of the "Bingen sand" of Veatch and later authors, and in McCurtain County, Okla., it comprises the lower part of the "Bingen formation" as shown on the geologic map of the State published in 1926 by the United States Geological Survey.

The area of outcrop is a belt extending from the valley of Little Missouri River in Pike County, Ark., west by south to the Oklahoma line, thence westward through the southern part of McCurtain, Choctaw, and Bryan Counties, Okla., and the northern parts of Red River, Lamar, Fannin, and Grayson Counties, Tex., and thence southward for many miles through central Texas. (See pl. 20.) In both southwestern Arkansas and McCurtain County, Okla., the Woodbine and the gravel and sand of the younger Tokio formation produce the southward-sloping Lockesburg cuesta, which is described on page 176 .

The formation has an estimated thickness of about 500 feet in southern Bryan and Choctaw Counties, Okla., and an apparent thickness of 625 feet in Fannin County, Tex., but it thins toward the east so that the thickness at most places in Arkansas is between 250 and 350 feet. It thins out on the west side of the valley of Little Missouri River, in Arkansas, and is not present east of this stream.

The formation has a southerly dip of perhaps 50 feet to the mile in most of the area shown on the accompanying map, though near the west end of the area it has been bent into a low anticline called the Preston anticline, whose axis extends southeastward through 


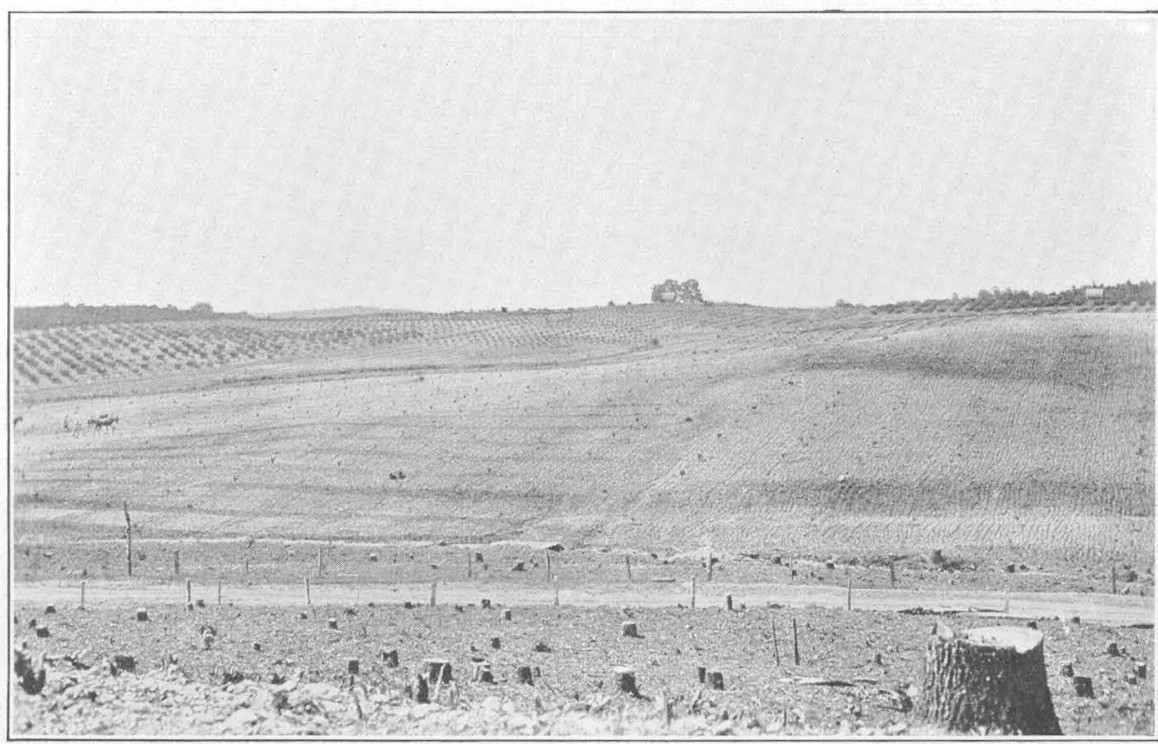

A. ROLLING “RED-LAND” COUNTRY ON LOCKESBURG CUESTA NEAR CORINTH, HOWARD COUNTY, ARK.

Underlain by gravel and tuff in the Woodbine and Tokio formations. Such country is especially adapted to growing peaches and other fruits. Photograph furnished by J. N. Garner

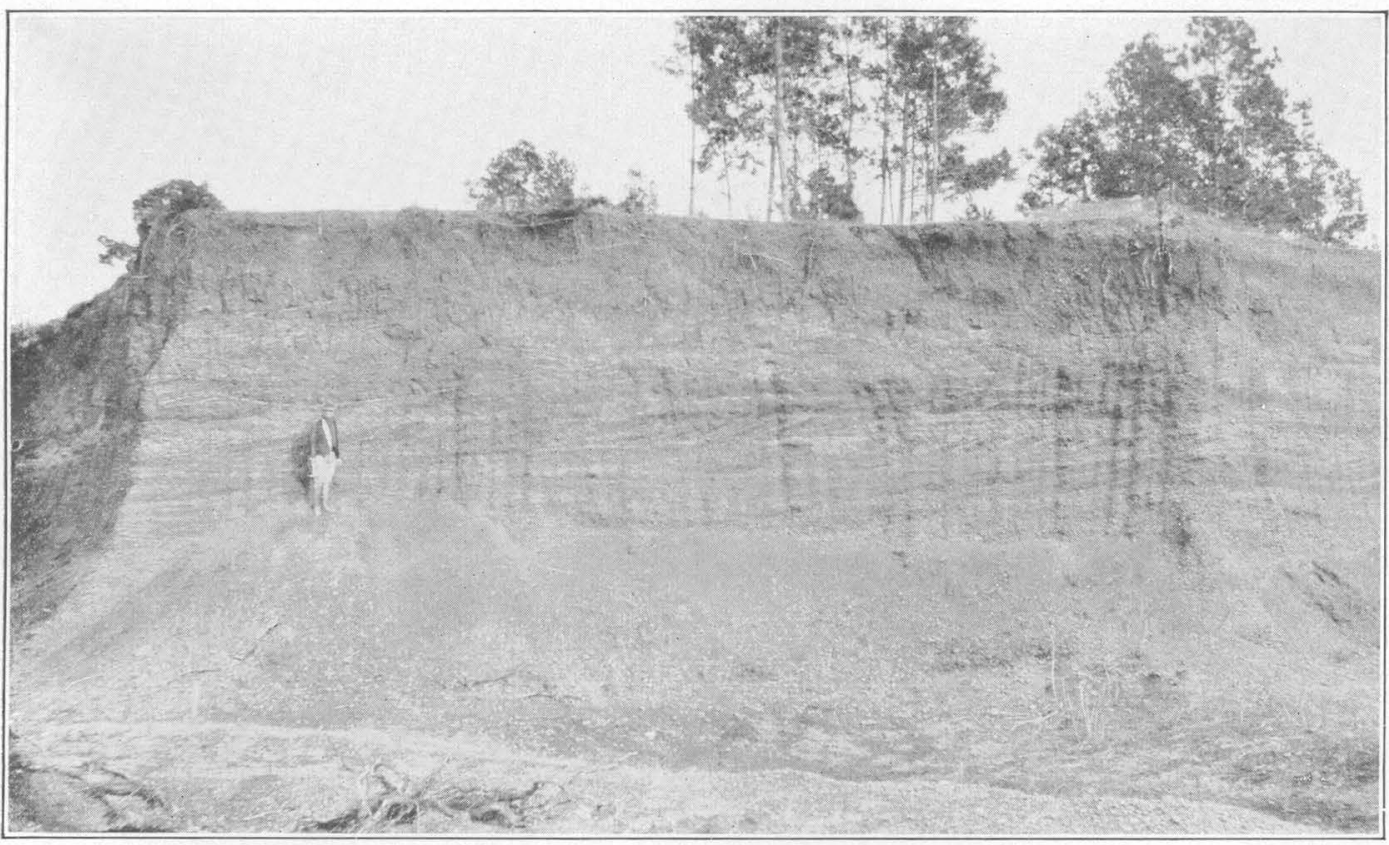

B. BASAL GRAVEL OF WOODBINE FORMATION IN GRAVEL PIT NEAR HORATIO, SEVIER COUNTY, ARK. Cross bedding is conspicuous. Photograph by P. D. Torrey 


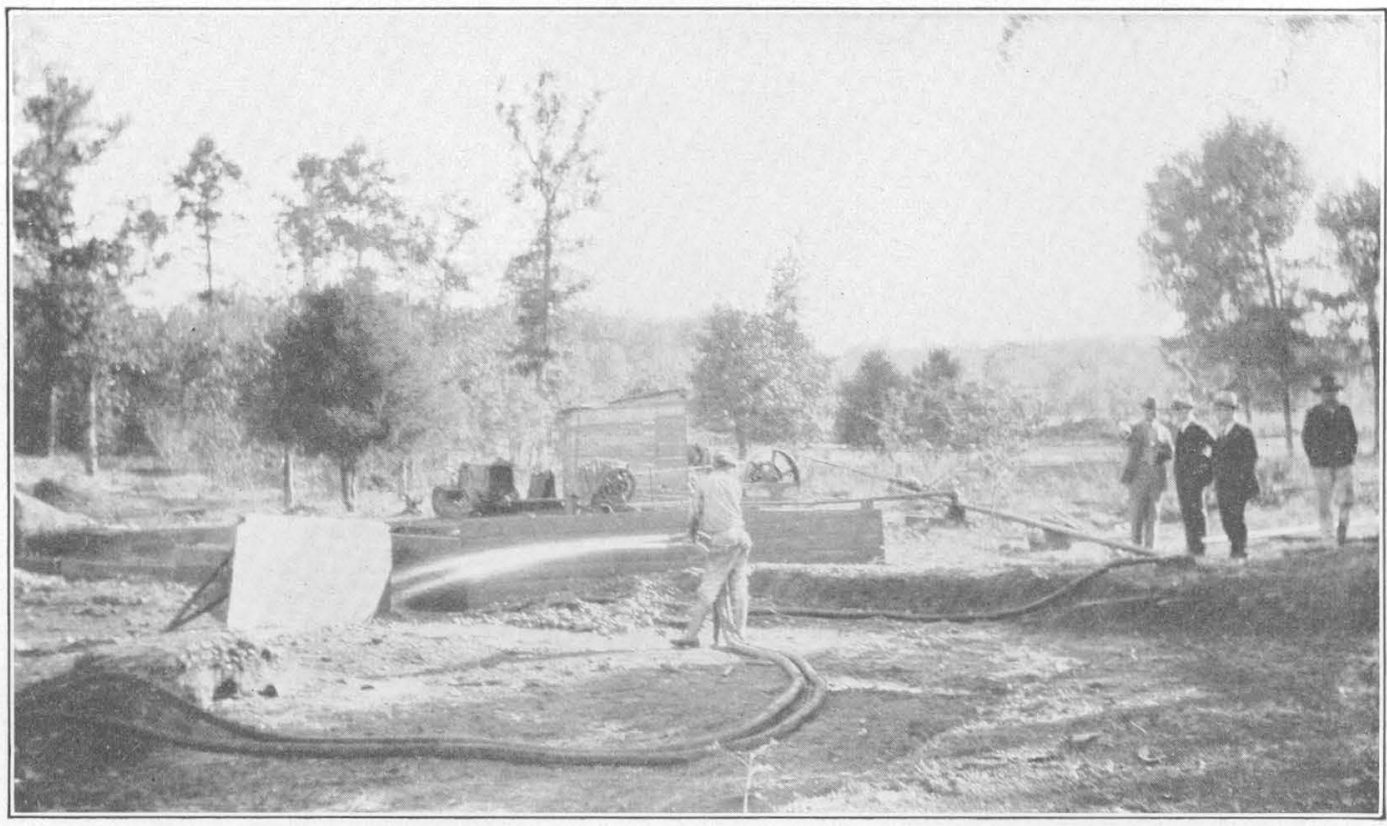

$A$

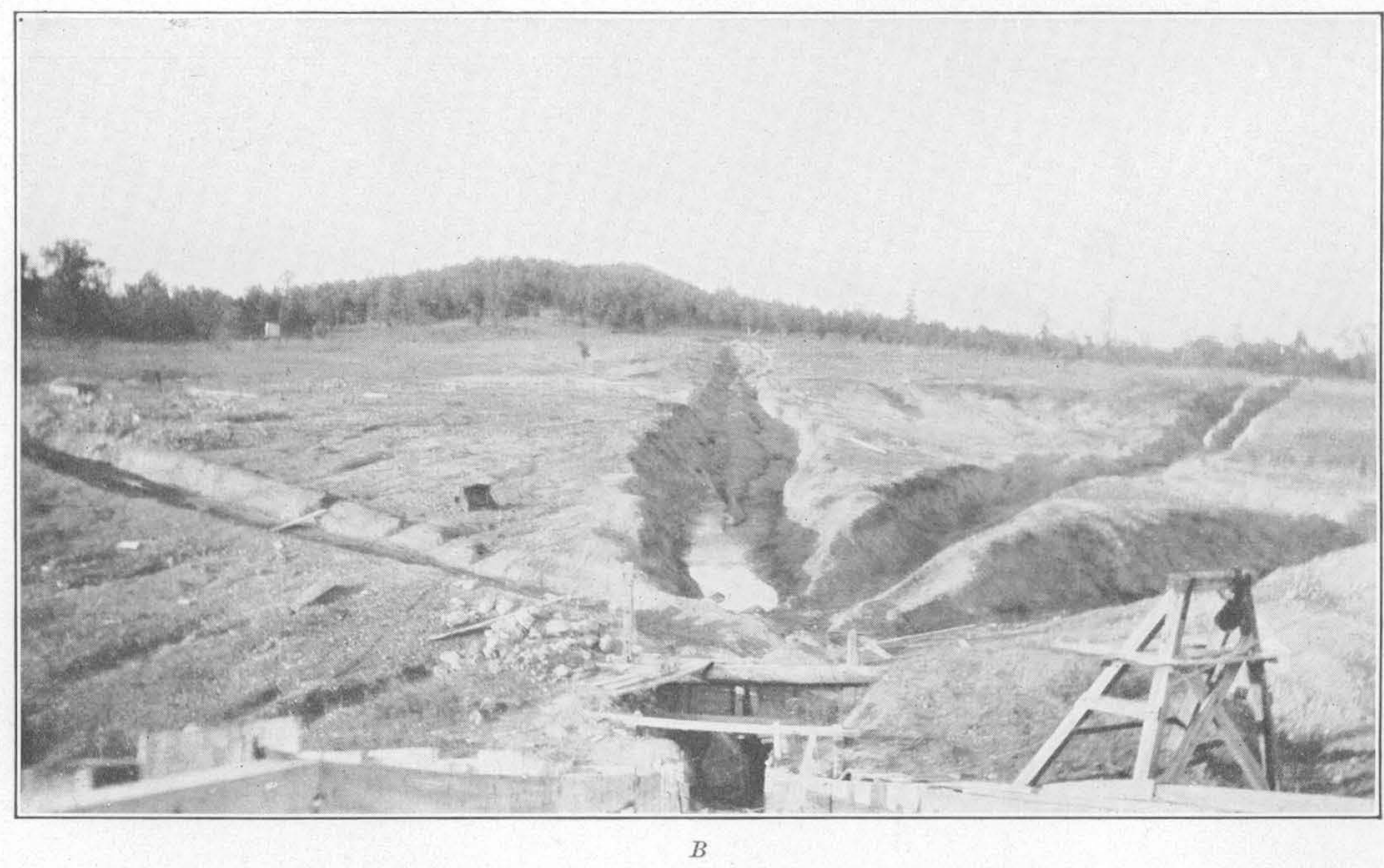

WEATHERED PERIDOTITE BRECCIA IN NECK OF CRETACEOUS VOLCANO NEAR MURFREESBORO, PIKE COUNTY, ARK. Contains diamonds. A shows diamonds being mined by hydraulicking. In $B$ the hill in the distance is partly capped by a mass
of Paleozoic sandstone that was lifted and carried upward during volcanic activity 


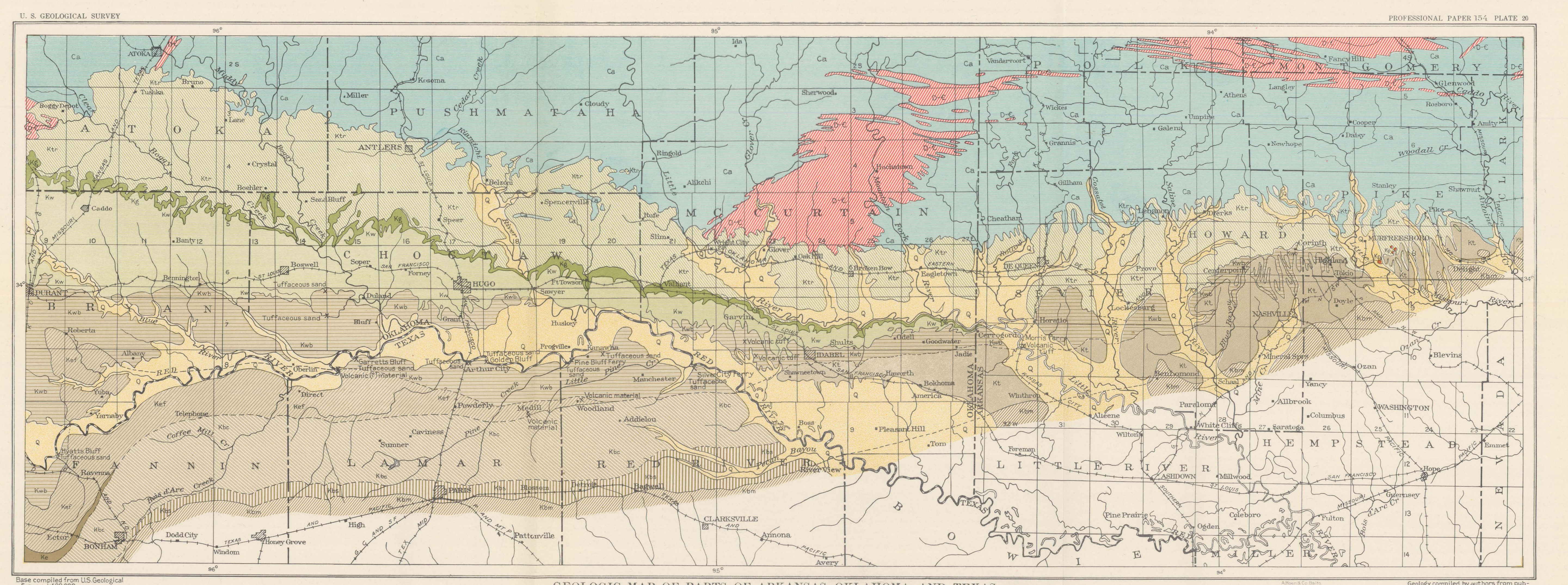

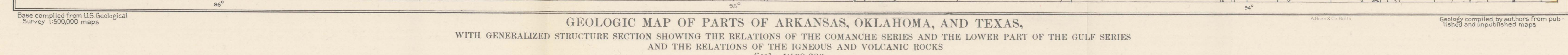

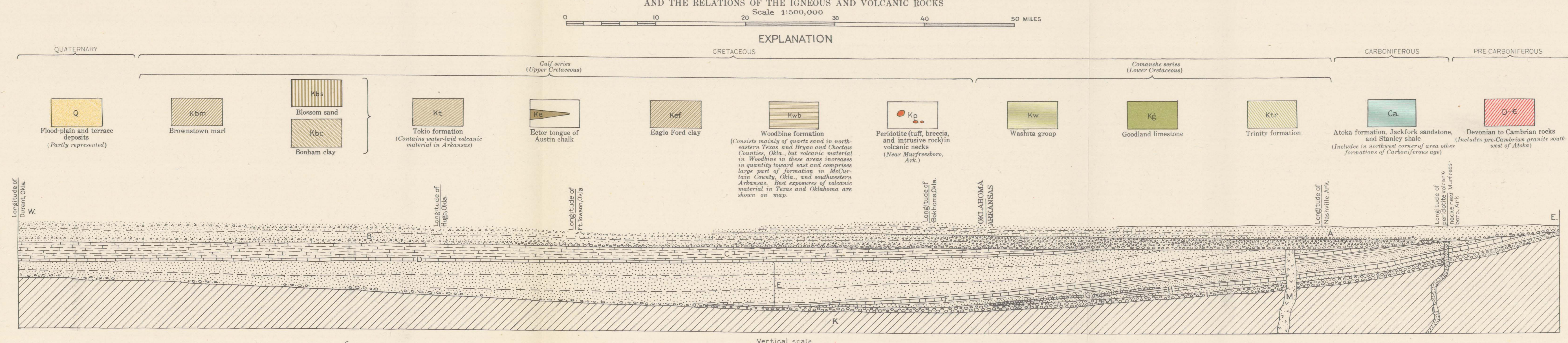

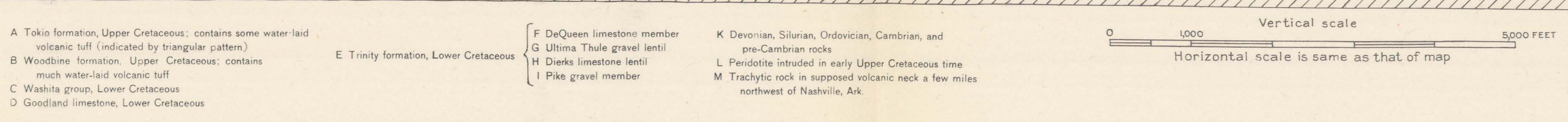



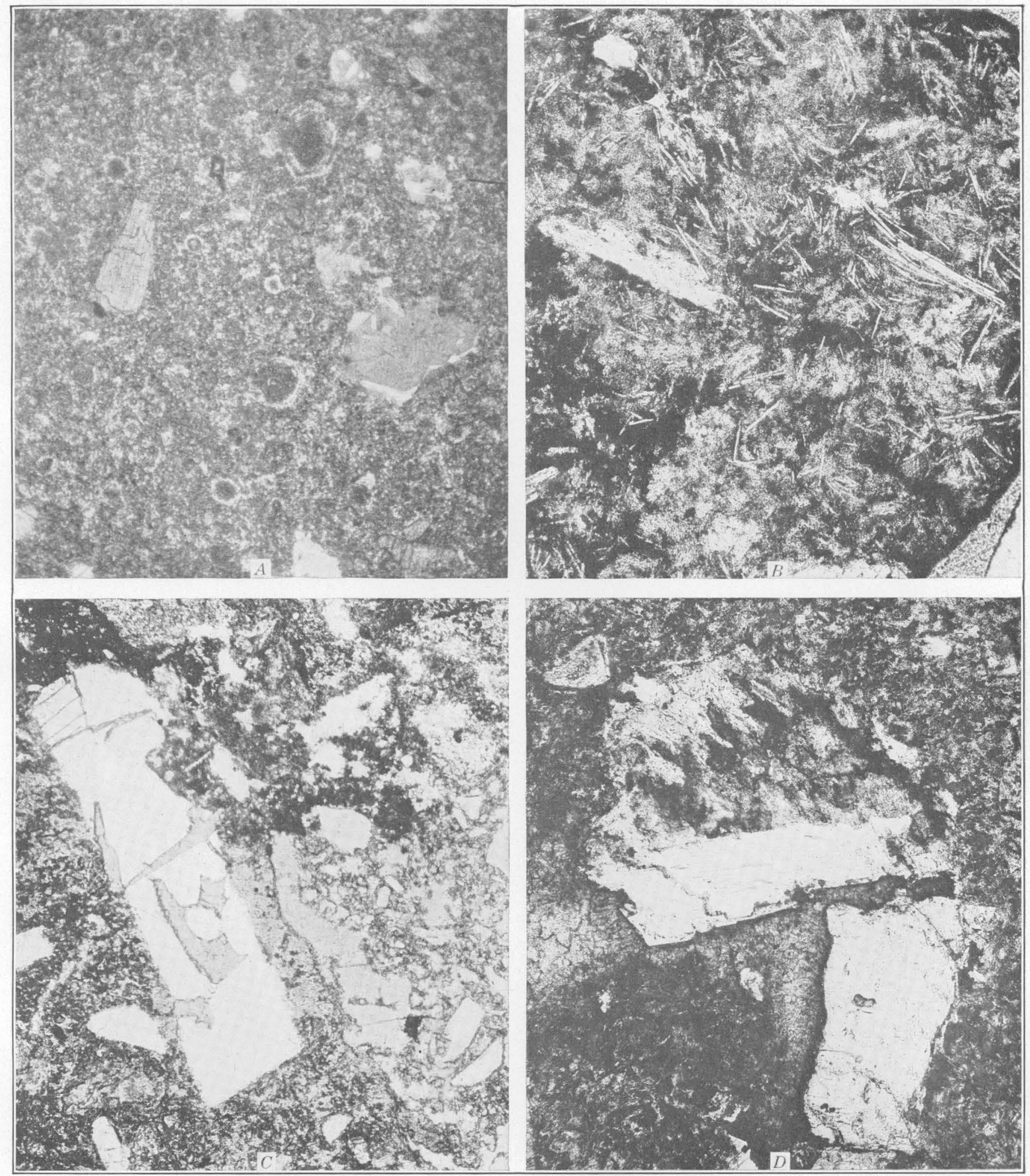

PHOTOMICROGRAPHS OF VOLCANIC ROCKS

A, Sodalite phonolite from boulder bed in Mine Creek near Nashville, Ark. The phenocrysts that show zoning are sodalite. Enlarged 34 diameters
$B$, Phonolite pellet from phonolite arkose, Owen place, Howard County, Ark. The elongated crystals are plagioclase, and the gray groundmass is a very fine grained orthoclase-albite aggregate. Enlarged 34 diameters
, Orthoclase crystal partly replaced by calcite, Owen place, Howard County, Ark. Enlarged 48 diameters

$D$, Orthoclase crystal partly replaced by calcite, Owen place, Howard County, Ark. The area with fingerlike extensions has the same optical orientation as the white central mass, and the dark area between is calcite. Enlarged 28 diameters 

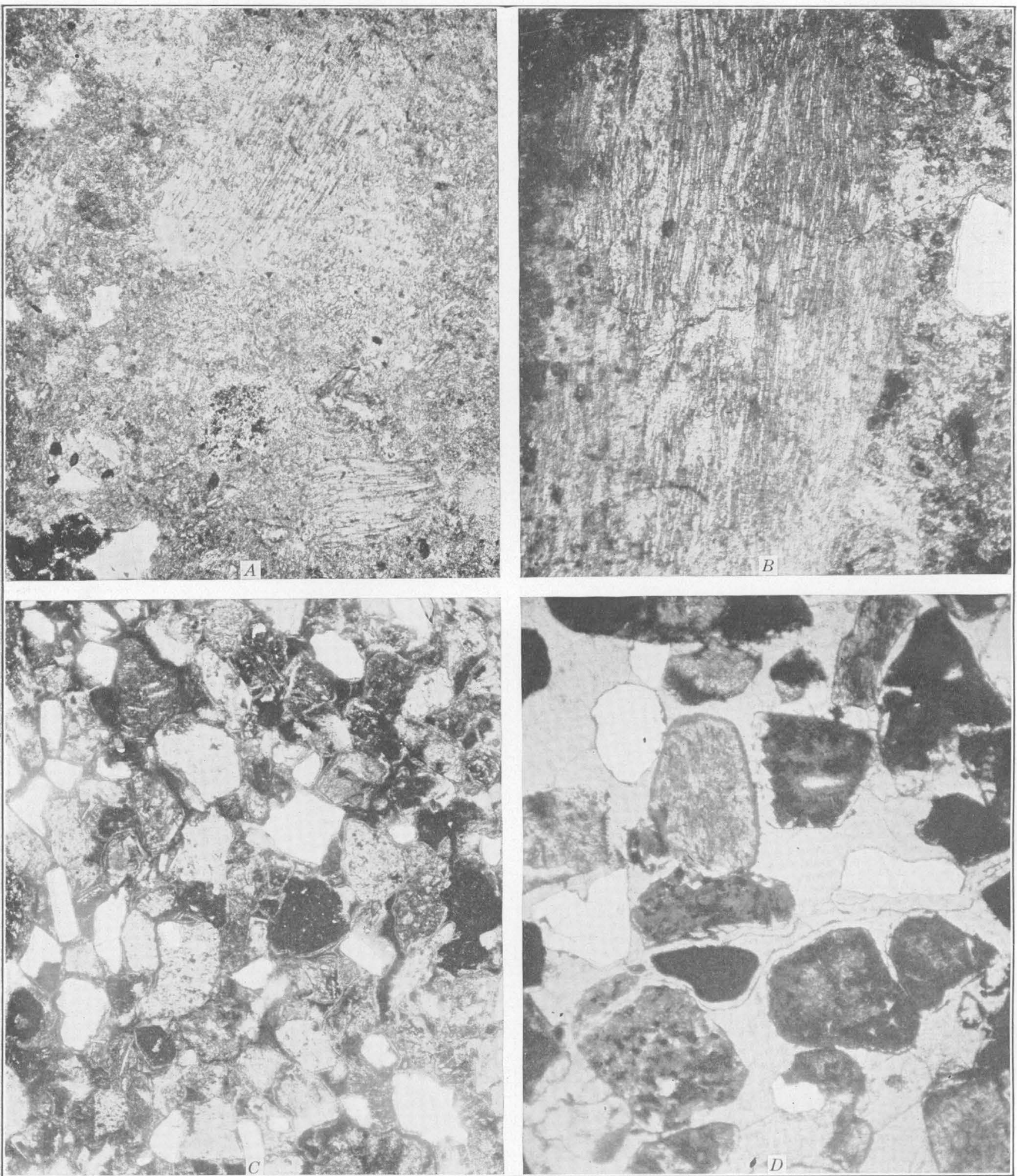

PHOTOMICROGRAPHS OF VOLCANIC ROCKS

A, Yoleanic tuff entirely replaced by calcite but preserving the structure of glassy pumice, Owen place, Howard County, Ark, Enlarged 54 diameters $B$, Part of a large glassy pumice fragment entirely replaced by calcite, Owen place, Howard County, Ark.

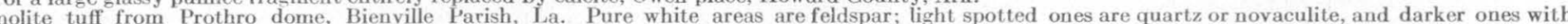
white elongated inclusions are phonolite. The interstitial material is glauconite. Enlarged 33 diameters
$D$. Phonolite tuff from Prothro dome, Bienville Parish, La. White angular areas are feldspar; rounded one, quartz; gray ones, phonolite pellets and partly replaced augite grains above and to the right of the center. Groundmass calcite. Enlarged 54 diameters 
the village of Ector, Fannin County, Tex., and it has also been bent into a syncline whose axis runs northwestward through Yuba, Bryan County, Okla.

The Woodbine rests upon the truncated edges of all the Comanche formations-the youngest subjacent formations to the west and the oldest to the eastand at the east edge of the area shown on the map (pl. 20) it rests upon steeply dipping beds of sandstone and shale of Carboniferous age. A marked angular unconformity therefore separates the Gulf series from the Comanche series in southwestern Arkansas and southeastern Oklahoma. (See section on pl. 20.)

The water-laid volcanic material in the Woodbine consists of tuffaceous sand in northeastern Texas and in Bryan and Choctaw Counties, Okla., and of tuff in McCurtain County, Okla., and in southwestern Arkansas. The sand and tuff, which are described in detail on pages 180 to 200 , occur in widespread beds that attain a thickness of 125 feet or more. These materials are mostly cross-bedded, soft, grayish and olivegray, are composed of coarse and fine grains of volcanic rocks, and are for the most part unconsolidated but in places cemented by calcite. The calcitecemented masses are lenticular or spherical.

Besides tuffaceous sand the Woodbine of northeastern Texas and of Bryan and Choctaw Counties, Okla., includes irregularly bedded quartz sand, which was deposited in shallow marine and brackish water. Interbedded with the sand are films, lenses, and layers of clay, which in places attain a thickness of 25 feet or more.

In Arkansas and in McCurtain County, Okla., there is a bed of gravel at the base of the formation and beds and lenses of gravel higher in the formation. (See pl. 18, B.) The gravel beds are thickest and most extensive in Arkansas, where the basal bed is continuous and attains a thickness of about 60 feet. The beds of gravel consist mostly of pebbles of novaculite, but in addition there are in Arkansas rather extensive deposits of pebbles of igneous rocks in the tuff, which overlies the basal gravel. Some of the larger igneous pebbles occur in the thick bed of gravel at the base of the formation, but most of them occur in thin beds and lenses of gravel interstratified in the tuff. Many small pebbles are, however, disseminated through the tuff. Clay is found at some places in beds many feet thick interbedded with the volcanic tuff. It is gray to brown, is laminated, and contains at places fossil leaves, some of which were collected at a locality on Mine Creek 4 miles north of Nashville, Ark.

\section{EAGLE FORD CLAY}

In western Lamar County and in Fannin County, Tex., the Woodbine sand is overlain, probably unconformably, by the Eagle Ford clay, which consists typically of 300 or 400 feet of dark, more or less bituminous clay carrying calcium carbonate concretions, in part septarian, some of which are fossiliferous.

The Eagle Ford is represented on Plate 20 as extending as a rapidly narrowing band eastward from Lamar County into Red River County in the vicinity of Woodland, but the beds thus mapped are not typical of the Eagle Ford clay. They consist of 50 or 60 feet of fine to coarse marine sand, a central band of which contains a small percentage of water-laid volcanic material. At the base of this sand just north of Woodland is a bed of conglomeratic sand, $11 / 2$ feet thick, containing many waterworn pebbles of novaculite reaching a diameter of 1 inch and reworked chunks of soft reddish sandstone. The Eagle Ford age of the sands near Woodland has not been satisfactorily established, and indeed there is some question as to whether they may not represent the basal part of the deposits of Austin age (Bonham clay) which overlie them within a mile south of Woodland. (See pp. 196-197.) The beds exposed within 4 or 5 miles north of Woodland are mostly sand and sandstone and are of Woodbine aspect, but future studies may show that they are in part of Eagle Ford age.

\section{TOKIO FORMATION}

The Tokio formation takes its name from the village of Tokio, at the northern edge or Hempstead County, Ark. The deposits when first defined by Miser and Purdue were described as the "Tokio sand member of the Bingen formation." Recent field work by Stephenson and Dane, in which Miser cooperated for short periods, has shown that an unconformity occurs at the base of a thick gravel bed immediately underneath the "Tokio sand member of the Bingen." It has also shown that the part of the "Bingen" below this gravel bed represents the Woodbine sand of Texas. As a result of this work and of a study of the fossils by Stephenson, the following changes in names have been made: The name "Bingen" has been discontinued; the lower part of the "Bingen"- the part below the unconformity-is called the Woodbine formation; and the "Tokio sand member of the Bingen" is now called the Tokio formation, though the lower limit of the new formation is extended so as to include the thick gravel at whose base there is an unconformity. The Tokio formation as thus defined has a basal gravel like the Woodbine, and each formation has an unconformity at its base. The formation in Arkansas rests upon lower and lower rocks toward the eastfirst upon the truncated edge of the Woodbine formation, then upon successive parts of the Trinity formation, and next upon the steeply dipping rocks of Paleozoic age. (See structure section on pl. 20.)

The Tokio formation is exposed in a belt extending west by south across several counties in southwestern 
Arkansas and thence into McCurtain County, Okla., at whose southern border the belt of exposure is terminated by alluvium and terrace deposits of Quaternary age along Red River. The belt of exposure is not continuous but is broken by bands of alluvium and terrace gravel along Little Missouri, Saline, Cossatot, and Little Rivers and other streams that cross it. The belt ranges in width from a few miles to about 12 miles and narrows eastward in consequence of the apparent thinning of the formation in this direction. The thickness is about 300 feet in the area west of Nashville, Ark., and is less east of Nashville.

The formation contains water-laid igneous materials near Murfreesboro, Pike County, Ark. These include thin beds that appear to be peridotite tuff and also include beds of kaolin that is apparently altered volcanic dust. These volcanic materials are described on pages 186 and 187. The formation is, however, composed largely of light to dark gray clay and gray sand that weathers yellowish and reddish. In addition there is much gravel in Arkansas, the thickest bed of which is at the base. The gravel is composed of well-rounded pebbles consisting of quartz and novaculite of many colors and ranging in size from that of a pea to a diameter of about 6 inches. The dark clay contains many invertebrate fossils, and some of it contains identifiable fossil plants. The proportions of clay and sand change both vertically and horizontally in the formation.

\section{CHARACTER OF VOLCANIC ROCKS}

\section{GENERAL FEATURES}

Most of the tuff occurs in the Woodbine formation. The main bed of volcanic material overlies the basal gravel of the formation and attains a thickness of 125 feet or more in the area lying between Center Point and Nashville, Ark. It consists of mineral grains, rock fragments, and pebbles in a claylike matrix.

The best exposures of volcanic material in Arkansas are on and near Mine Creek, Blue Bayou, and other streams near Center Point and Nashville. (See fig. 17.) Near Blue Bayou Church, 4 miles south of Center Point, the principal mineral in the sand bars of Blue Bayou is orthoclase in glistening transparent grains that have been derived from near-by exposures of tuff. The best exposures in Oklahoma are near Odell and Garvin; there the tuff is characterized by the occurrence of "black sand" and limonitic "buckshot" in the gullies. In Arkansas and Texas these minerals are not abundant enough to be conspicuous in gullies.

In northeastern Texas water-laid tuffaceous material, the westward extension of the tuffaceous beds of the Woodbine of Arkansas, forms a considerable part of the sand of the Woodbine formation, especially in the upper beds.
Coarse tuffaceous sand containing notable amounts of volcanic materials has been fexamined at six localities (pl. 20), which are alined in an approximate east-west direction in the northern parts of Red River and Lamar Counties, as follows: At Silver City Ferry, 17 miles north of Clarksville, at a locality 2 miles east of Kanawha, and at Pine Bluff Ferry, 41/2 miles north of Woodland, in Red River County; at Golden Bluff, 3 miles east of Arthur City, at the bluff near Arthur City, and at Garretts Bluff, 13 miles west of Arthur City, in Lamar County. Similar coarse tuffaceous sand in approximately the same stratigraphic position has been observed at Hyatts Bluff, 5 miles northwest of Ravenna, Fannin County. The locality east of Kanawha in Red River County has yielded large typical specimens of Ostrea soleniscus Meek, a characteristic Woodbine species. Smaller, less typical specimens, probably belonging to the same species, occur at Golden Bluff, in Lamar County, at a horizon 30 feet above the top of the main bed of tuffaceous sand. (See pls. 25-27.)

Volcanic material makes up a small percentage of a sandstone of questionable Eagle Ford age in the vicinity of Woodland, in the northwestern part of Red River County, and a similar slightly tuffaceous sandstone occurs at Medill, in the northeastern part of Lamar County. These localities are between 4 and 5 miles south of the main east-west belt of tuffaceous sandstone, and on the assumption that the regional dip of the beds toward the south is not less than 50 feet to the mile, this upper tuffaceous bed should be 200 feet or more stratigraphically above the main tuffaceous bed. Other beds of tuffaceous material may occur between the main bed and the uppermost bed, but this has not yet been demonstrated. At Woodland and Medill the tuffaceous sandstone is immediately overlain by the Bonham clay, which belongs stratigraphically above the Eagle Ford clay.

A sandstone containing a small percentage of tuffaceous material was observed in a bluff on Red River, $11 / 2$ miles north of Ragtown, in the northwestern part of Lamar County. This sandstone lies near the top of the Woodbine formation about 12 feet stratigraphically below the base of the Eagle Ford clay, which is well developed in this area.

The tuffs and tuffaceous sands of southwestern Arkansas, southeastern Oklahoma, and northeastern Texas were for the most part deposited in shallow water and under the influence of strong currents. They are mixed in various proportions with detrital material derived from the Paleozoic rocks on the north, and parts of the tuffs themselves were reworked and redeposited. All this has resulted in a very intimate mixing of the various types of volcanic and detrital materials and an obscuring of the volcanic history. The geologic study is still further complicated by an intense alteration of the glassy tuffs, which has left 
them in the form of clay beds. Nevertheless some layers in the tuffs, especially in the vicinity of Nashville, Ark., are composed of volcanic débris that shows little mixing of the volcanic rocks, and this has made possible a recognition of the principal rock types and rock textures that have contributed to the formation of the volcanic beds of the region.

The volcanic material that occurs in greatest volume and with the widest distribution is in the form of are probably a finely crystalline phase derived from the same magma that formed the glassy tuff. Accompanying these materials are crystal grains, which represent the phenocrysts that were ejected along with the tuff.

\section{LITHIC PHONOLITE TUFF AND SAND}

The most widely distributed volcanic material occurs in the form of small rounded rock pellets that average

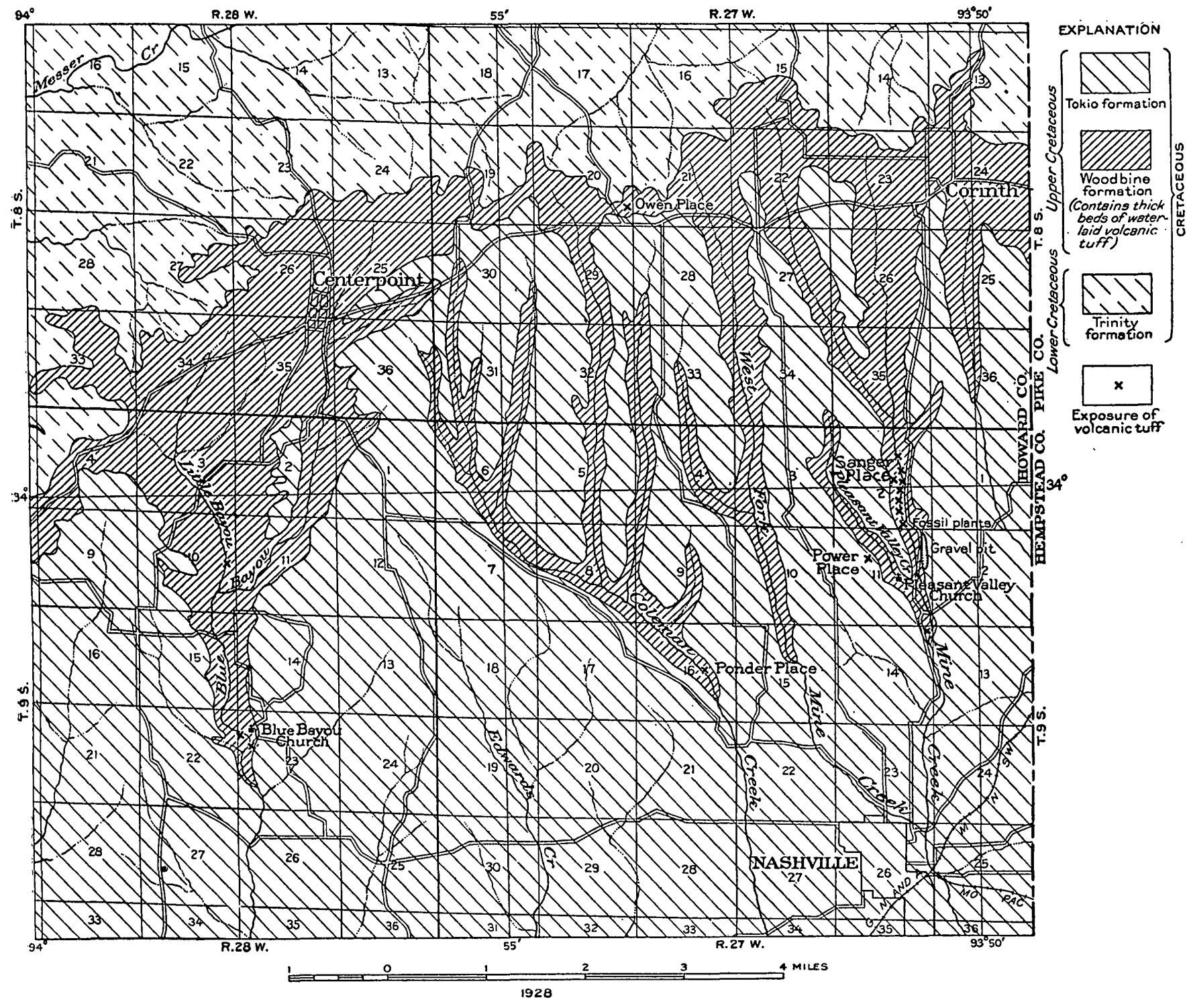

Fraure 17.-Map of part of Howard County, Ark., showing the surface distribution of the volcanic deposits of the Woodbine formation

rounded lithic rock grains that average between 0.5 and 1 millimeter in diameter. Interbedded with the tuff are beds of gravel and boulders, which are composed predominantly of quartz and novaculite but which locally contain well-rounded boulders of the same volcanic rock types as the material in the lithic tuff.

Near Nashville are extensive beds of material that was originally glassy pumiceous tuff. Associated with this are angular lithic tuff and rock fragments that
0.5 to 1 millimeter in diameter. The color of the unweathered rock is dark olive-green to dark graygreen. On weathering the material assumes various shades of yellow and brownish red. Beds made up almost wholly of fragments of volcanic rock have been recognized in a few localities, and this material may be called lithic tuff, but more commonly the fragments of volcanic rock are mixed with some grains of quartz and novaculite, and this material is more correctly described as tuffaceous sand. (See pl. 22, $C, D$.) 
The volcanic rock structure is clearly recognizable in all thin sections, even in the rocks that have completely lost their original minerals through kaolinization. The rounded rock pellets are characterized by a single volcanic rock type, and the only difference is a slight one in texture and mineral proportions. (See pl. 21, B.) They all show a trachytic structure, and many have a parallel arrangement of the slender plagioclase crystals of the ground mass. The rock of the pellets is all of very fine grain, and the crystals of the groundmass range from 0.02 to 0.3 millimeter in greatest length. Anhedral orthoclase is abundant; and nephelite is often recognizable despite the fineness of grain. The rock grains rarely carry phenocrysts, as these were not abundant and were usually set free by the explosive violence that pulverized the rock.

The mineral grains associated with the lithic phonolite tuff and sand are orthoclase, plagioclase, augite, hornblende, zircon, apatite, and magnetite. Titanite, biotite, and black spinel are found in some beds, but it seems probable that these minerals were derived from the admixed pumice tuff and not from the phonolite. Brown tourmaline, garnet, and staurolite, which are characteristic of metamorphic rocks, are present in small amounts and are associated with the typical minerals of igneous rocks in the tuff. Secondary minerals that have developed in the beds after their deposition are siderite, calcite, pyrite, glauconite and phosphatic granules.

\section{PHONOLITE COBBLES}

Well-rounded cobbles and pebbles are found locally in the beds and lenses of gravel associated with the tuff and are especially abundant on Mine Creek, near Nashville, Ark. (See fig. 17.) Few pebbles in the tuff are more than 2 or 3 inches in diameter, but the cobbles in the gravel reach 9 or 10 inches in diameter.

The rock type that makes up 75 per cent or more of the cobbles is the same as that forming the phonolite pellets and is represented by the analysis on page 187 . The rock structure is shown in Plate $21, B$. The rock is dark gray with a very fine grained groundmass and phenocrysts of sodic plagioclase and orthoclase forming less than 5 per cent of the mass. Augite is still rarer and is seldom seen in a hand specimen. The microscope shows a rock with trachytic structure and groundmass crystals which range from 0.02 to 0.3 millimeter in length and many of which have a common orientation. The range in mineral composition of the phonolite is as follows:

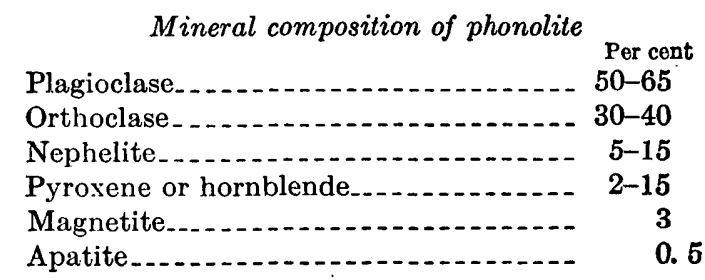

The orthoclase forms anhedral crystals between the euhedral plagioclase crystals. The nephelite is in part anhedral and in part euhedral and forms very small interstitial crystals. Augite occurs as phenocrysts and in the groundmass, but forms less than 3 per cent of the rock in the predominant type of phonolite. In a few specimens it is more abundant and may reach 15 per cent. Green or brown hornblende is a rare constituent. One specimen examined was similar to the predominant type of rock but contained a small proportion of sodalite. (See pl. 21, A.)

Nearly all the phonolite from the gravel and most of the rock pellets in the tuff are very fine grained and commonly show flow structure or orientation of the feldspar grains and so have a structure characteristic of volcanic rocks, but a rare rock type that occurs in the boulders has the texture of an intrusive. This is a fourchite with abundant augite and nephelite.

\section{PUMICE TUFF}

In the vicinity of Nashville, Ark., are extensive beds composed partly or almost wholly of materials' that originally formed a tuffaceous volcanic pumice. This pumice has completely lost its glassy texture and is most commonly represented by bentonitic claylike material, but locally concretionary calcium carbonate has cemented the pumice fragments into boulderlike forms that have escaped this type of alteration.

The predominant color in the claylike material is gray to light blue-gray where unweathered; after oxidation it is yellow. The boulders with calcite cement are pale buff. The pumice fragments differ widely in size, ranging from 0.1 to 50 millimeters in diameter. The pumice has a fibrous structure that resulted from the presence of very fine, closely spaced elongated or flattened vesicles separated by very thin glass walls. In the claylike beds consolidation has slightly compressed and flattened the altered pumice fragments and eliminated the vesicles, but the fiberlike pumiceous texture has been perfectly retained. (See pl. 22, B.) In hand specimens the clay has little resemblance to tuff, but thin sections exhibit the tuff structure as perfectly as the original glass.

The pumice beds contain mineral grains representing phenocrysts that were set free from their glassy matrix by the explosive force of the eruptions that produced the pumice itself. Most of these crystals are euhedral or have one end perfect and the other fractured, but in some beds the crystals are strongly etched, though none of them are well rounded by transportation and abrasion.

The minerals are orthoclase, biotite, titanite, magnetite, zircon, apatite, and black spinel. Augite and hornblende possibly occur in very small amount but are probably derived from the phonolite and not from the trachyte. Orthoclase is very abundant and may 
form as much as 25 per cent of the rock, but the other minerals are rare and form less than 1 per cent. The metamorphic rock minerals tourmaline, garnet, and staurolite occur in small proportions in tuff of all types. Phosphatic grains and glauconite were probably formed during deposition, and siderite, calcite, and pyrite have developed after deposition.

\section{LITHIC TRACHYTE ROCK FRAGMENTS}

Crystalline rock fragments are associated with the pumice tuff and in some localities form as much as 50 per cent of the material. The pumice and the trachyte always occur together and carry the same minerals, and it seems evident that one is the glassy and the other the crystalline phase of the same igneous magma. They show little sorting, large and small rock fragments occurring together. In this they differ from the phonolite rock fragments, which are well rounded and usually well sorted. The pumice and orthoclase trachyte show much less mixing with foreign material than the phonolite, and some beds are composed of pure igneous material.

The orthoclase trachyte rock fragments range from 1 to 20 millimeters in diameter and are angular or knotted. They are white or light gray and are composed of phenocrysts of orthoclase in a groundmass that is a very fine grained aggregate of anhedral feldspar. Euhedral orthoclase phenocrysts are abundant in some fragments and nearly absent in others. Biotite, titanite, and black spinel in fine euhedral crystals are very sparsely present.

\section{DETAILED DESCRIPTION OF MINERALS} IGNEOUS ROCK MINERALS

Orthoclase.-The pumice and lithic tuff of trachytic composition contain abundant orthoclase, and the lithic phonolite tuff and sand contain small proportions. The orthoclase crystals range from 0.3 to 3 millimeters in diameter but average about 1.5 millimeters. Most of the crystals have been fractured, probably by the explosive eruptions, but most of them show one or more perfect crystal faces, and Carlsbad, Manebach, and Beveno twins are not rare. Some crystals have been etched, as described on page 185 and pictured in Plate 21, $C, D$, and there is practically no rounding of the fragments of tuff near Nashville, Ark., but in other areas there is slight rounding of some of the crystals. Nearly all the crystals show great clearness, but a few have inclusions of glass. The optical axial angle is small in most crystals and nearly uniaxial in many, and these characters indicate that the mineral is the sanidine variety of orthoclase.

Augite.-In the phonolite tuff augite is the second most abundant mineral, but in the pumice and trachyte tuff it is rare or absent. Most of the crystals are pale bottle-green in millimeter-sized grains and colorless in thin section, but a few are faintly lavender in thin section. Nearly all have the peculiar cockscomb termination shown in Plate 24, $A$. The origin of these forms is discussed on page 184 .

Biotite.-Dark-brown euhedral flakes of biotite are present in the pumice and trachyte tuff but form less than 1 per cent of the rock.

Hornblende.-Many separations of heavy minerals have been made by means of heavy solutions, and slender hornblende crystals are always present, but they form only a fraction of 1 per cent of the tuff. They are brilliant black in millimeter-sized grains and usually olive-green in thin section, but a few have the reddish-brown color of basaltic hornblende. The crystals reach 3 or 4 millimeters in length and most of them are euhedral, but some of those separated from the tuffaceous sand of Oklahoma and Texas are slightly rounded by abrasion, although none of them show etching.

Titanite.-All the igneous rocks of the region contain titanite, but it is especially abundant in the pumice and trachyte tuff. It forms brilliant golden-yellow crystals that average less than 1 millimeter in diameter. Most of them are perfectly euhedral and show almost no fracturing or rounding by attrition, but a few are slightly etched.

Magnetite and spinel.-Magnetite is present in all the tuffs, and black spinel is most abundant in the pumice and trachyte tuff. Both have very sharp euhedral faces, but the crystals are usually pitted or incompletely developed. The magnetite can be separated from the spinel with a hand magnet, and then it is noticed that the spinel has much more brilliant black faces than the magnetite. The spinel is opaque except in exceedingly fine grains.

Apatite and zircon.-Apatite and zircon are present in all the heavy minerals that have been separated. The apatite is usually colorless, but a few grains are a fine blue. The zircon is colorless to deep lavenderpink.

\section{SECONDARY MINERALS}

Siderite.-Small grains of siderite have been formed in most of the tuff beds, probably before the calcite, for small crystals of siderite are completely inclosed in calcite. Siderite is found in the calcite concretions in the phonolite, in uncemented phonolite tuff and tuffaceous sand, and in the bentonitic material derived from the pumice. It most generally forms small euhedral rhombs, but also some knotlike pellets and a few well-rounded radially fibrous grains similar to grains of sphaerosiderite. A few boulder-like masses several inches in diameter are composed almost entirely of siderite. The color is yellow to reddish brown, and the index of refraction indicates that much of the material is nearly pure iron carbonate. 
The siderite grains weather out of the tuff and become oxidized to limonite. These grains become concentrated by flowing water and form accumulations of shotlike grains in the steam beds throughout the region.

Calcite.-The tuff and tuffaceous sand of Arkansas contain concretions cemented with calcite that reach a maximum diameter of several feet. In the Texas and Oklahoma areas some beds are completely cemented with calcite, and the same relation is shown in the Louisiana localities that contain tuff identical in character with that of Arkansas, Oklahoma, and Texas. The calcite commonly forms large crystals, some of them 4 to 5 centimeters in diameter, that inclose large numbers of mineral and rock grains.

Pyrite.-Small rounded crystalline aggregates and octahedrons of pyrite have been formed abundantly in some of the tuff beds subsequent to their deposition.

Phosphatic grains.- Small rounded grains of phosphatic material were probably formed together with the marine type of glauconite on the sea bottom during the deposition of the beds.

Glauconite.-The tuff in some localities, especially that from the Prothro salt dome, Bienville Parish, La., contains rounded glauconite grains. These are bluish green, are composed of the usual aggregate of overlapping crystal plates, and were probably formed on the sea bottom. Most of the tuff beds of the phonolite type contain some proportion of a yellowish-green mineral, with a habit entirely dissimilar to that of the normal glauconite. This mineral has developed in the tuff since its deposition, as it has replaced augite and phonolite grains with various degrees of completeness and has slightly replaced calcite. It forms narrow zones around all mineral and rock grains in many beds of the phonolite tuff and is the cause of the green color in most of these beds. It forms radial zones of a micaceous mineral with a high birefringence and a mean index of refraction of about 1.62. Qualitative chemical tests show the presence of essential potash and indicate that the material is glauconite or possibly celadonite.

\section{MINERALS CHARACTERISTIC OF METAMORPHIC ROCKS}

Nearly all crops of heavy minerals separated from the tuff contain very small proportions of minerals that are characteristic of metamorphic rocks. The most generally distributed of these is brown tourmaline, but pale-pink garnet and staurolite are occasionally seen. Some fragments of these minerals are rounded, but many are sharply angular, and much of the tourmaline is euhedral. There is no direct evidence as to the source of these minerals, but it is possible that deeply buried metamorphic rocks were shattered and small quantities of their mineral components carried to the surface together with the normal. volcanic material by the violence of the volcanic eruptions. This supposition is supported by the presence at the diamond mines near Murfreesboro, Pike County, Ark., of rather large blocks of Paleozoic sandstone that are believed to have been blasted from their position and carried to the surface, and fragments of norite that must have been derived from some deepseated source have also been recognized in rock from the same locality. (See pl. 19.)

\section{REPLACEMENT OF MINERALS SUBSEQUENT TO SEDIMEN- TARY DEPOSITION}

The augite grains from all the tuff beds show multiple terminating pyramids that produce the cockscomblike habit shown in Plate 24, $A$. Calcite-cemented concretions have been formed in the tuff bedsof Arkansas subsequent to their deposition, and in parts of Texas and at the Prothro salt dome, La., the beds are completely cemented by calcite. Thin sections of tuff from the Owen place, Ark. (fig. 17), and the Prothro dome give a clue to the mode of formation of the augite crystals with the cockscomb habit. In many localities of the region a film of glauconitic material was deposited around each grain of rock or mineral soon after its deposition. Thus the original form of the augite crystals was preserved. Later the augite was partly replaced by calcite or etched by solutions that permeated the beds. In their present form the augite grains show each a dark zone of glauconitic material that marks the original boundary of the crystal; within that is a zone of calcite that represents replaced augite; and the core is perfectly fresh augite with cockscomb habit. ${ }^{\circ}$ (See pl. 23, C.) Not uncommonly the replacement has progressed so far that two or more completely isolated augite areas that are in uniform optical orientation have developed from a single original grain, as shown in Plate $23, B$. The multiple terminations were not present on the original augite grains and have developed entirely as a result of secondary processes. Most of the tuff beds in the Arkansas area do not have an interstitial cement of calcite, but in these the augite grains also show the cockscomb habit. It is evident that carbonate-bearing waters were present in all the beds of the Woodbine formation, and it seems probable that these were capable of corroding and etching augite. In many of the Texas and Oklahoma localities the replacement of augite is complete, and the characteristic form of the replaced crystal is all that remains to indicate that augite was once present. The pyroxene has been altered to glauconite after partial replacement by calcite, and interstitial glauconite and films of glauconite around mineral grains are characteristic of several localities. One of these grains is pictured in Plate $24, D$. All these changes took place only after the deposition of the material, and they present abundant 
evidence that glauconite is not necessarily formed on the sea bottom but can result from the replacement of preexisting minerals.

Augite crystals with the cockscomb habit have been observed in material from northern New Mexico and Montana and are illustrated in Plate 24, B, C. Those from Montana were slightly rounded before the secondary crystal faces were developed.

Most of the orthoclase crystals show euhedral faces, but a few have been embayed and replaced by calcite, as shown in Plate 21, $C, D$.

All the other minerals of igneous rocks are unaltered and unreplaced by calcite. Hornblende is unetched, and the original crystal faces are often brilliant and perfect. Thus it is evident that augite was not stable under the conditions that controlled the deposition of these sedimentary beds and was subject to solution or replacement, whereas under the same conditions hornblende was stable.

\section{ALTERATION AND WEATHERING OF TUFFS}

The volcanic tuffs throughout the region are composed largely of materials that were not stable under the physical conditions that promoted solution and hydration (in the zone of katamorphism) and so have undergone very extensive alteration. Some of these changes were produced by ordinary weathering, but others are more profound.

Fresh phonolite tuff and tuffaceous sand are greenish gray or dull olive-green. They are very porous, and their easy permeability has resulted in rather deep weathering in much of the region. Where weathering is complete they have assumed a red or reddish-brown color, but the less deeply weathered material is rusty brown.

The crystalline materials have resisted alteration much more than those with glassy texture, and so many of the individual phonolite grains are little affected by even the more intense alteration processes. In some beds, however, the feldspar of some of the rock fragments has been kaolinized and the original minerals have been more or less replaced by secondary ones.

As the phonolite cobbles are all very well rounded they must have been transported and eroded prior to deposition in their present situation. Many of them have been weathered and show an outer kaolinized zone an inch or more in thickness. Fresh and weathered pebbles are found side by side, in places below the permanent water level of the creek beds. This indicates that the kaolinization of the pebbles took place before deposition. As the glassy tuff was altered to bentonite after deposition, kaolinization and the formation of bentonite are two processes that took place at different times and probably under different conditions.

\section{BENTONITE}

Throughout most of the Arkansas area the glassy pumiceous tuff of the Woodbine formation has been altered to a bentonite that contains a large proportion of igneous-rock phenocrysts and detrital rock fragments, but locally calcite concretions have formed in the pumice tuff soon after deposition and prevented the formation of bentonite.

Bentonite is a rock composed predominantly of clay and formed by the alteration and devitrification of glassy volcanic material, usually a tuff. It generally contains differing porportions of igneous-rock phenocrysts and admixed detrital débris. Most bentonites contain montmorillonite as their characteristic clay mineral, but the bentonite of southwestern Arkansas is composed of beidellite. ${ }^{13}$ This mineral has been found in one other sample of bentonite ${ }^{14}$ and in gouge clays from mineral veins, ${ }^{15}$ and it is an abundant soil and clay forming mineral, which has the chemical formula $\left(\mathrm{Al}_{2} \mathrm{O}_{3}, \mathrm{Fe}_{2} \mathrm{O}_{3}\right)$. $3 \mathrm{SiO}_{2} \cdot \mathrm{nH}_{2} \mathrm{O}$, where $\mathrm{n}$ is about 4 . The mineral is plastic and has a micaceous habit and high birefringence. An analysis of Arkansas bentonite has been made by Earl V. Shannon, of the United States National Museum, who, together with C. S. Ross, has been engaged in a study of bentonite. The igneous rock from which the Arkansas bentonite has been derived has been analyzed by George Steiger, of the Geological Survey.

The conditions that promote the change of volcanic glass to bentonite have not been well known, but mineral relations in the Arkansas area permit some deductions as to the physical environment that favored the change. The development of bentonite was not due to surface weathering but to causes that affected all glassy materials at all observable depths, and in the same beds feldspar, all ferromagnesian minerals, and fragments of lithic tuff are commonly unaltered. The lime concretions that were formed in the tuff beds have preserved very delicate pumice fragments with uncollapsed bubble walls, as shown in Plate 22, $A, B$, and evidently the infiltrating calcium carbonate was introduced before the formation of the bentonite. The calcium was no doubt transported as bicarbonate, and it is quite probable that the water was bicarbonate bearing throughout the period of alteration. The ash fell in a marine embayment, and the entrapped water may have remained saline during alteration, but it

${ }^{13}$ Larsen, E. S., and Wherry, E. T., Leverrierite from Colorado: Washington Acad. Sci. Jour., vol. 7, pp. 208-217, 1917; Beidellite, a new mineral name: Idem, vol. 15, pp. 465-466, 1925. Ross, C. S., and Shannon, E. V., The chemical composition and optical properties of beidellite: Washington Acad. Sci. Jour., vol. 15, pp. 467-468, 1925; The minerals of bentonite and related clays and their physical properties: Am. Ceramic Soc. Jour., vol. 9, pp. 77-96, 1926.

14 Ross, C. S., and Shannon, E. V., Am. Ceramic Soc. Jour., vol. 9, pp. 77-96, 1926.

is Larsen, E. S., and Wherry, E. T., Leverrierite from Colorado: Washington Acad. Sci. Jour., vol. 7, pp. 208-217, 1917. 
is impossible to determine the degree of dilution with fresh water. The ash fell in water, and calcite concretions were present when the alteration took place, and therefore volcanic gases and acids stronger than the dissolved carbon dioxide were not present and could have had no part in the alteration. It. seems equally certain that organic or so-called humic acids were absent, for no extensive plant remains are ássociated with the beds, and a very great thickness of material has been affected by the processes of alteration.

The known factors of the alteration were the absence of oxidizing conditions, the presence of water for hydration, the removal of excess chemical constituents, and the probable presence of bicarbonates, sodium chloride, and possibly of magnesium salts from the sea water. Calcium carbonate and iron carbonate leave a record of their transportation probably as bicarbonates, but soluble alkaline bicarbonates would leave no such record and so may or may not have been present. The absence of sulphate minerals like gypsum indicates that sulphates were absent or practically absent from the solutions. No other factors suggest themselves that are likely to have contributed to the formation of bentonite. Thus it seems improbable that the alteration of volcanic glass to bentonitic clay was brought about by unusual chemical conditions. On the other hand, it seems to have been the result of hydration and solution of an unstable glass that was perhaps more or less aided by the presence of chlorides and bicarbonates, the latter probably in very weak concentration.

Analyses of the trachyte that is believed to have approximately the same composition as the pumice, of the bentonite from Mine Creek, and of other related clay minerals are given in the following table:

Analyses of trachyte, bentonitic clay from Mine Creek, Howard County, Ark., and related clays

\begin{tabular}{|c|c|c|c|c|}
\hline & 1 & 2 & 3 & 4 \\
\hline \multirow{8}{*}{ 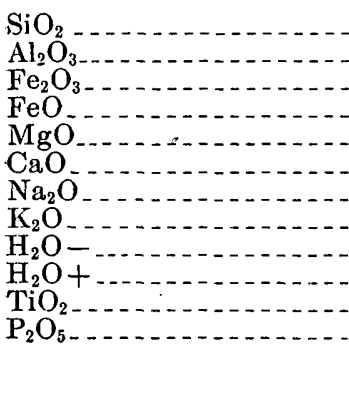 } & $\begin{array}{r}62.97 \\
19.00 \\
1.13\end{array}$ & $\begin{array}{r}45.12 \\
28.24 \\
4.12\end{array}$ & $\begin{array}{r}47.28 \\
20.27 \\
8.68\end{array}$ & $\begin{array}{r}48.80 \\
21.08 \\
.92\end{array}$ \\
\hline & .26 & 2.32 & 70 & 484 \\
\hline & .54 & .88 & 2. 75 & 1. 36 \\
\hline & 2. 86 & & .97 & $(a)$ \\
\hline & $\begin{array}{r}10.80 \\
.72\end{array}$ & 18.72 & $\begin{array}{l}\text { Trace } \\
19.72\end{array}$ & 20. 92 \\
\hline & 1. 26 & $\ldots$ & & - \\
\hline & $\begin{array}{l}.26 \\
.10\end{array}$ & & & \\
\hline & 99. 90 & 99.40 & 100. 37 & 97. 92 \\
\hline
\end{tabular}

a About 2 per cent alkalies.

1. Trachyte, Coleman Creek, Howard County, Ark. George Steiger, analyst.

2. Bentonitic mineral concentrated from bentonite derived from trachytic pumice, Mine Creek, Howard County, Ark. Earl V. Shannon, analyst.

3. Clay mineral from Beidell, Colo. Edgar T. Wherry, analyst. Larsen, E. S., and Wherry, E. T., Washington Acad. Sci. Jour., vol. 7, p. 213, 1917.

4. Bentonitic mineral concentrated from bentonite, Ardmore, Nebr. Earl V. Shannon, analyst.
The analyses given above show the chemical relations of the bentonitic mineral to the rock from which it was derived. Analysis 1 represents the porphyritic trachyte with a very fine crystalline groundmass, but the relation of pumice to trachyte and the identity of the associated phenocrysts indicate that one was the glassy and the other the crystalline phase derived from the same magma. The norm of the trachyte given on page 187 shows that it was a highly alkalic rock with less than 4 per cent of quartz and indicates that the Arkansas bentonite was derived from a rock low in quartz and high in alkalies. No analyses have previously been available of material that was known to have altered to bentonite, but the presence of the igneous rock minerals has led to the belief that bentonite was derived from glassy rocks high in alkalies and less silicic than normal rhyolites. ${ }^{16}$

Analyses 1 and 2 show the chemical changes involved in the alteration of glass to bentonite. It is probable that there has been little addition or abstraction of $\mathrm{Al}_{2} \mathrm{O}_{3}$ during the alteration of the glass, but the alkalies have been almost completely abstracted. This indicates that it has taken about $1 \frac{1}{2}$ parts of the trachyte pumice to produce each part of the resulting bentonite, which would require the removal of about half the original silica to give a final product with 47.23 per cent of silica. There appears to have been a moderate addition of iron, and a rather large addition of magnesium was probably derived from the sea water that was present during alteration. The other great change was the addition of water and the production of hydrated minerals.

\section{KAOLINIZED VOLCANIC MATERIAL}

One or more beds of kaolinized volcanic material having a thickness of 5 feet occur in the Tokio formation between Murfreesboro and Delight, Ark. (See pl. 20.) The material is chalky white to creamy, but the lowest layer of one bed has a lavender color. It is nonplastic, is very fine grained, and breaks with a conchoidal fracture. The volcanic material is known locally as kaolin and has been so designated by all geologists ${ }^{17}$ who have heretofore written on the region. A description of the kaolin deposits and a discussion of their economic value are given on pages 201 and 202 .

The altered volcanic material is very pure clay, and microscopic studies indicate that it is composed of pellet-like fragments, the largest of which are less than 1 millimeter in diameter. The internal structure of the pellets resembles that of altered feldspar, but the same structure seems to be characteristic of some clay minerals. The structure therefore does not give clear evidence of the origin of the kaolin. Kaolin is a

${ }_{10}$ Ross, C. S., and Shannon, E. V., The minerals of bentonite and related clays and their physical properties: Am. Ceramic Soc. Jour., vol. 9, p. 84, 1926.

17 Branner, J. C., The clays of Arkansas: U. S. Geol. Survey Bull. 351, pp. 147-153, 1908. Miser, H. D., and Purdue, A. H., Gravel deposits of the Caddo Gap and De Queen quadrangles, Ark.: U. S. Geol. Survey Bull. 690, p. 24, 1918. 


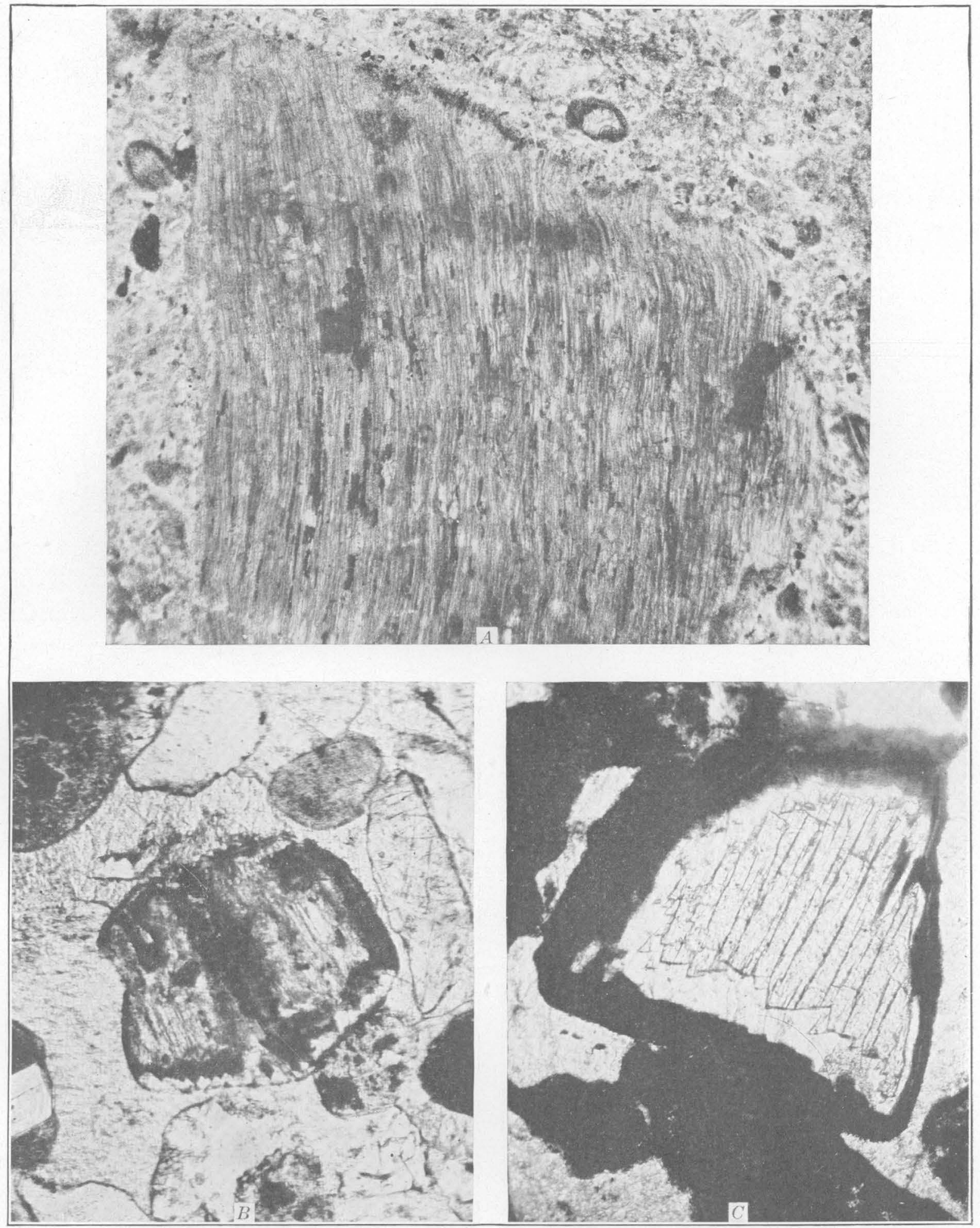

PHOTOMICROGRAPHS OF VOLCANIC ROCKS

A, Thin section of bentonitic volcanic tuff from Coleman Creek near Nashville, Ark. The large fragment was originally glassy pumice of orthoclase trachyte composition but is now completely altered to the clay mineral beidellite. Groundmass is fine-grained material of the same type. Phiarged 62 diameters

Ren place, between Center Point and Corinth, Howard County, Ark. The central grain is augite partly replaced by calcite Replacement has left two residual areas of augite that extinguish simultaneously under crossed nicols and have saw-tooth secondary terminal diameters

$C$, Augite grains from Original outline of crystal fragment marked 

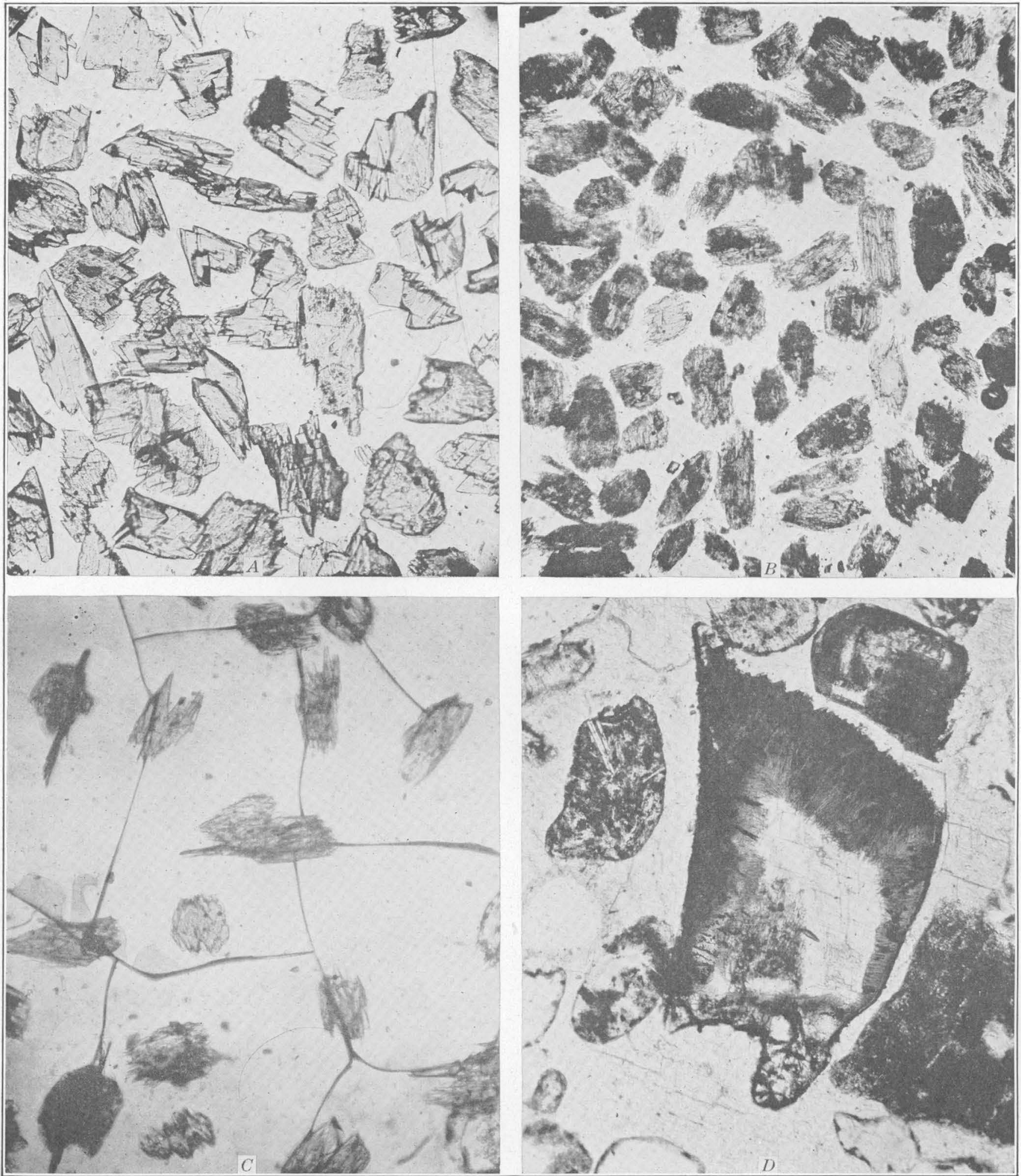

PHOTOMICROGRAPHS OF VOLCANIC ROCKS

A, Augite grains from phonolite tuff, Owen place, near Nashville, Ark. Secondary saw-tooth crystal faces have developed through corrosion and replacement $B$ by calcite. Enlarged 34 diameters

$B$, Etched augite grains from San Antonio Creek, Rio Arriba County, N. Mex. Enlarged 34 diameters 2 diameter $D$, Augite grains partly replaced by glauconite and calcite, Prothro dome, Bienville Parish, La. Grains at left are phonolite. Groundmass is caleite. Enlarged
100 diameters 


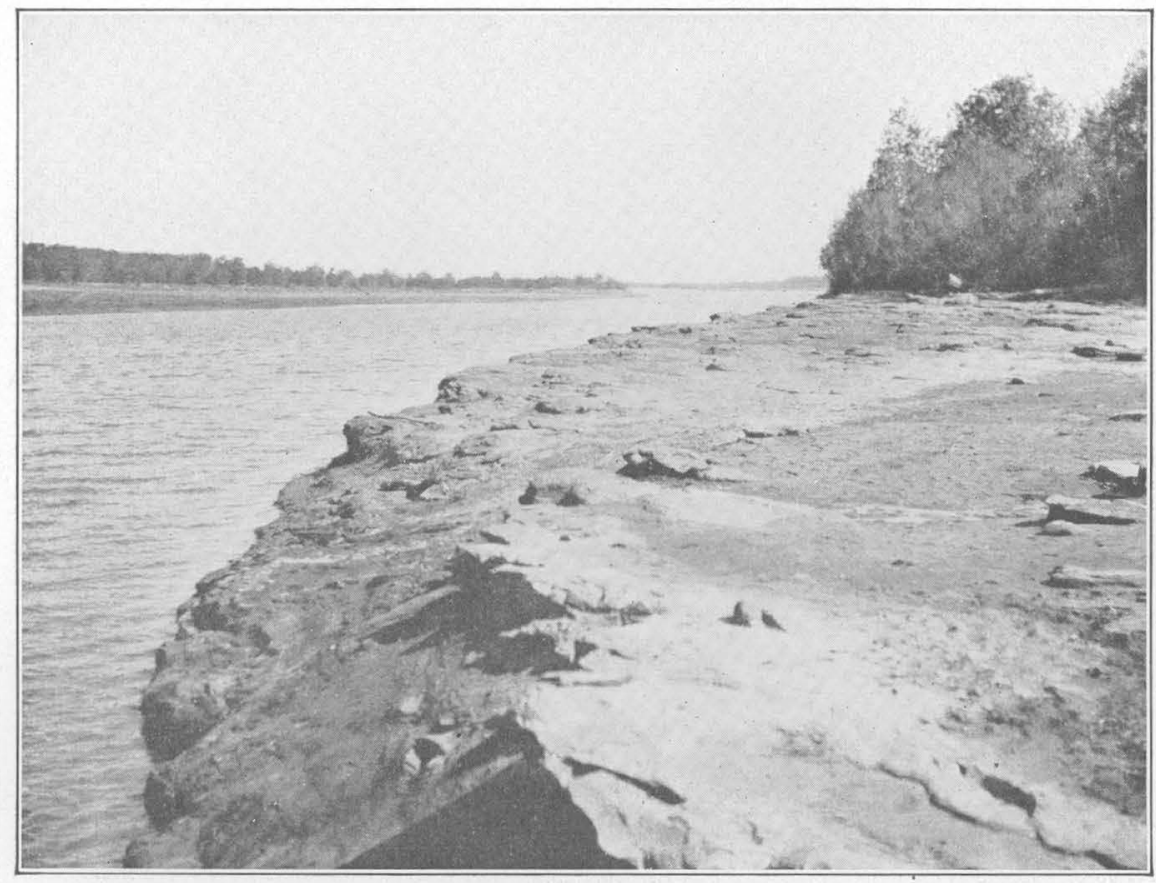

A. TUFFACEOUS SANDSTONE OF THE WOODBINE FORMATION AT SILVER CITY FERRY, RED RIVER, RED RIVER COUNTY, TEX.

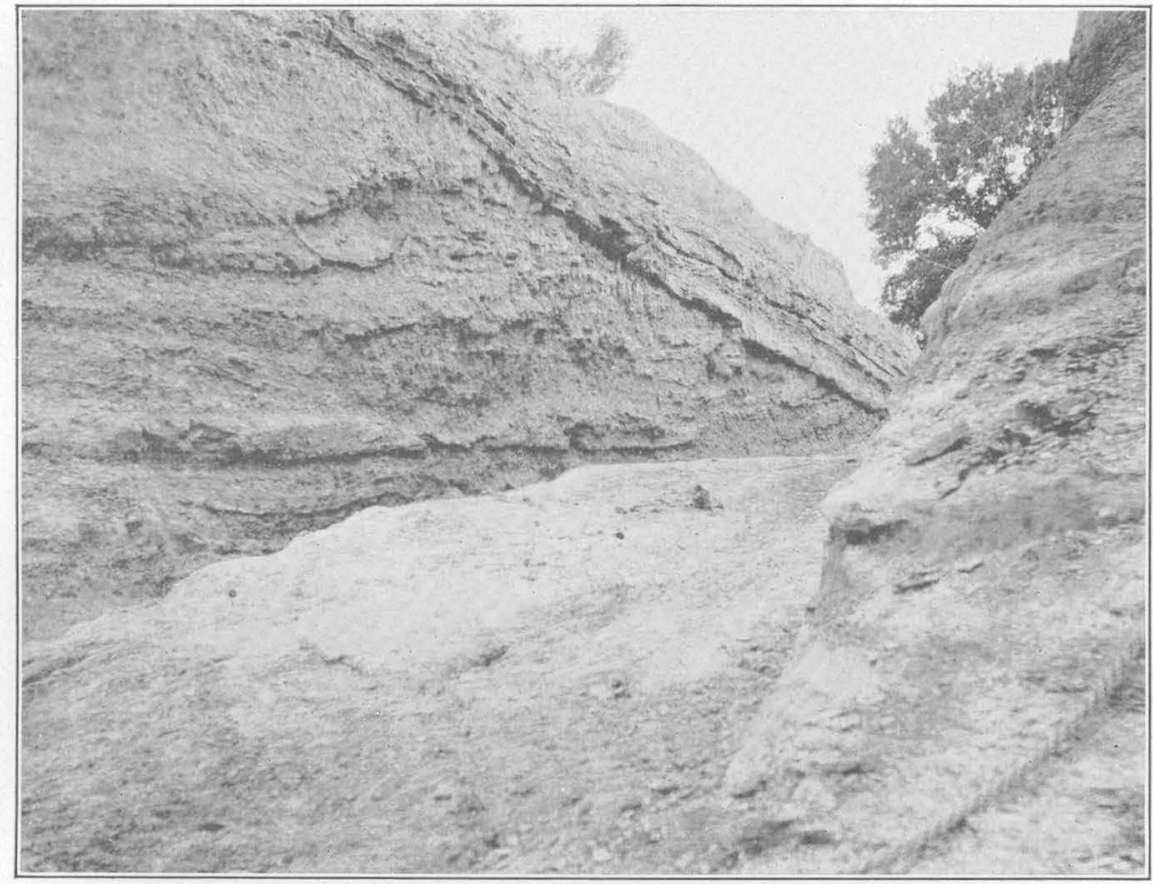

B. IRREGULARLY BEDDED SAND AND CLAY OF THE WOODBINE SAND IN ROAD CUT LEADING DOWN TO THE LOWER FERRY AT ARTHURS BLUFF, RED RIVER, LAMAR COUNTY, TEX.

Most of the fossil leaves from this locality described by E. W. Berry were obtained in the lower part of the section shown in the picture 


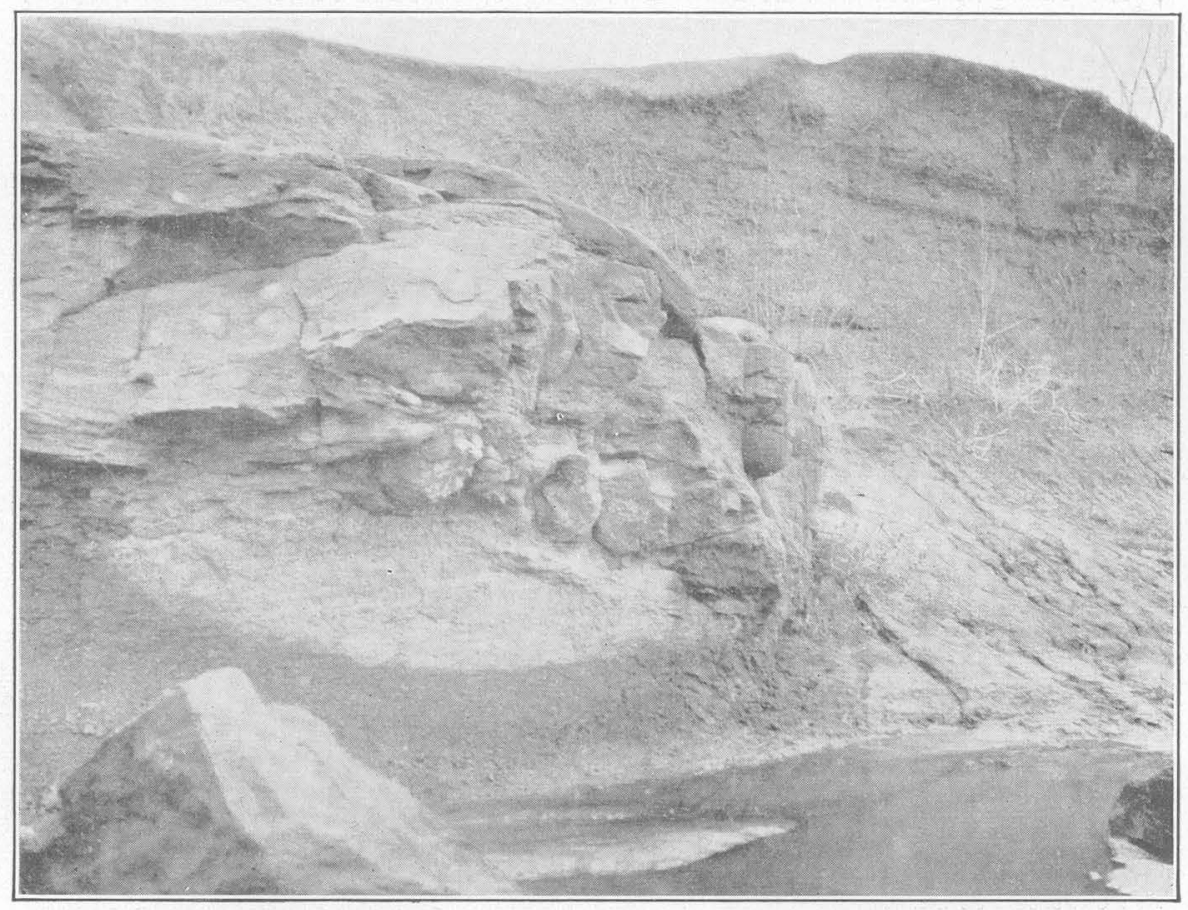

A. LENS OF TUFFACEOUS SAND IN LAMINATED SANDY CLAY OF THE WOODBINE FORMATION, ABOVE THE LOWER FERRY AT ARTHURS BLUFF, RED RIVER, LAMAR COUNTY, TEX.

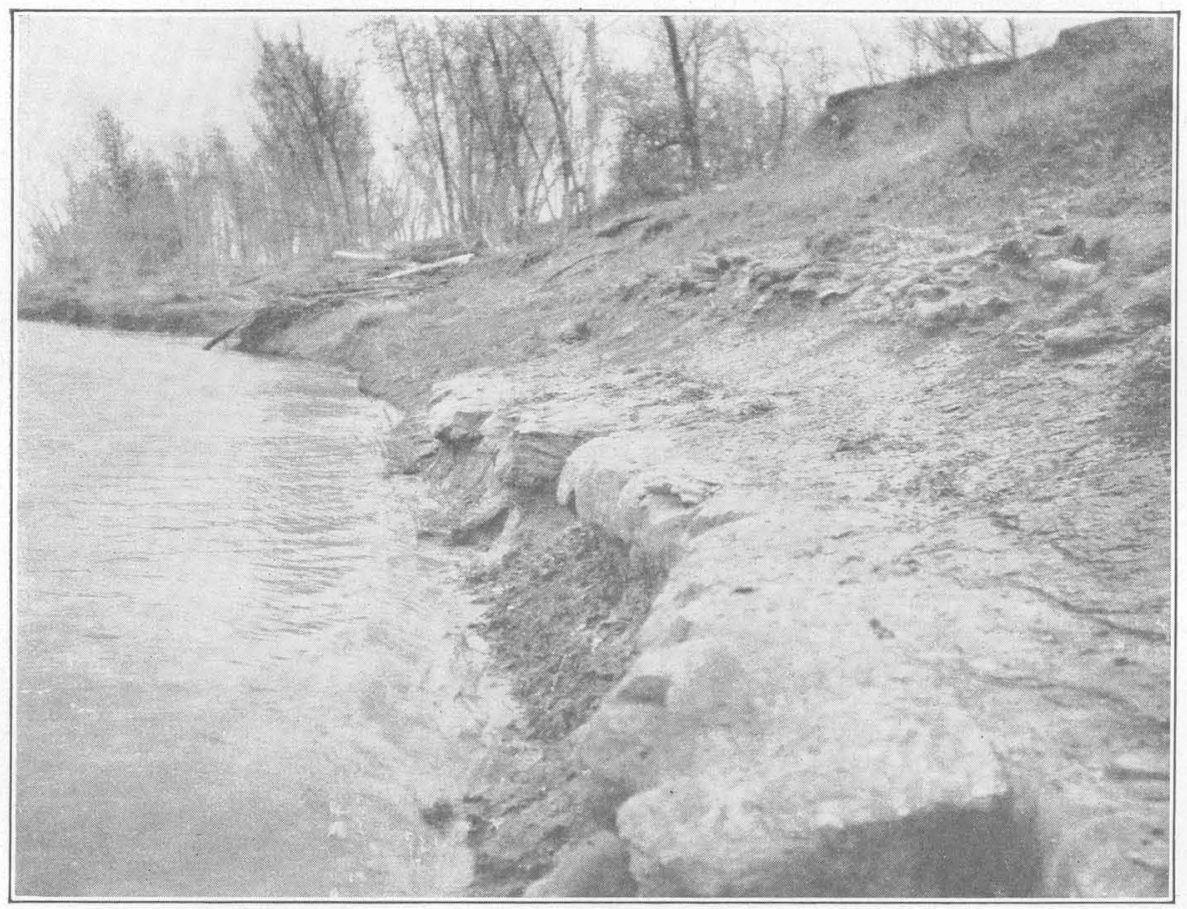

B. TUFFACEOUS SANDSTONE OF THE WOODBINE FORMATION, BELOW THE LOWER FERRY AT ARTHURS BLUFF, RED RIVER, LAMAR COUNTY, TEX. 


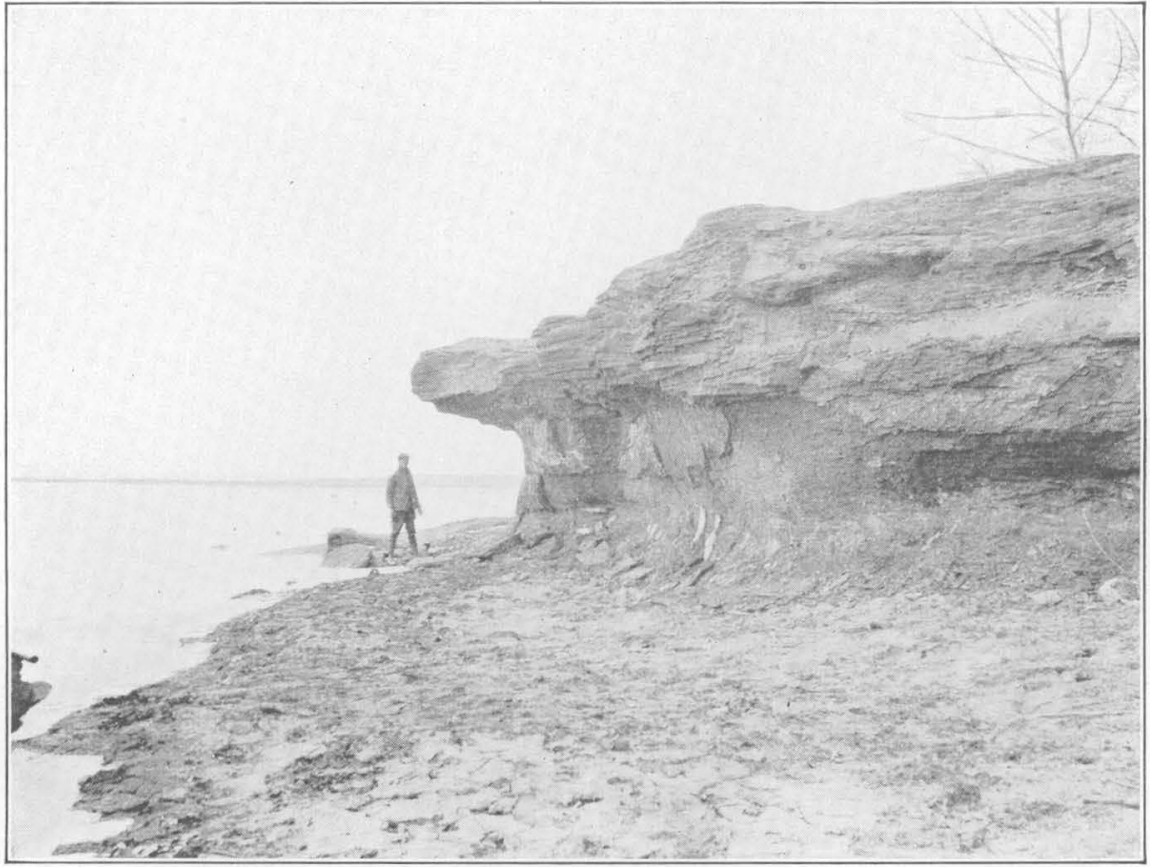

A. TUFFACEOUS SANDSTONE OF THE WOODBINE FORMATION AT HYATTS BLUFF, RED RIVER, FANNIN COUNTY, TEX.

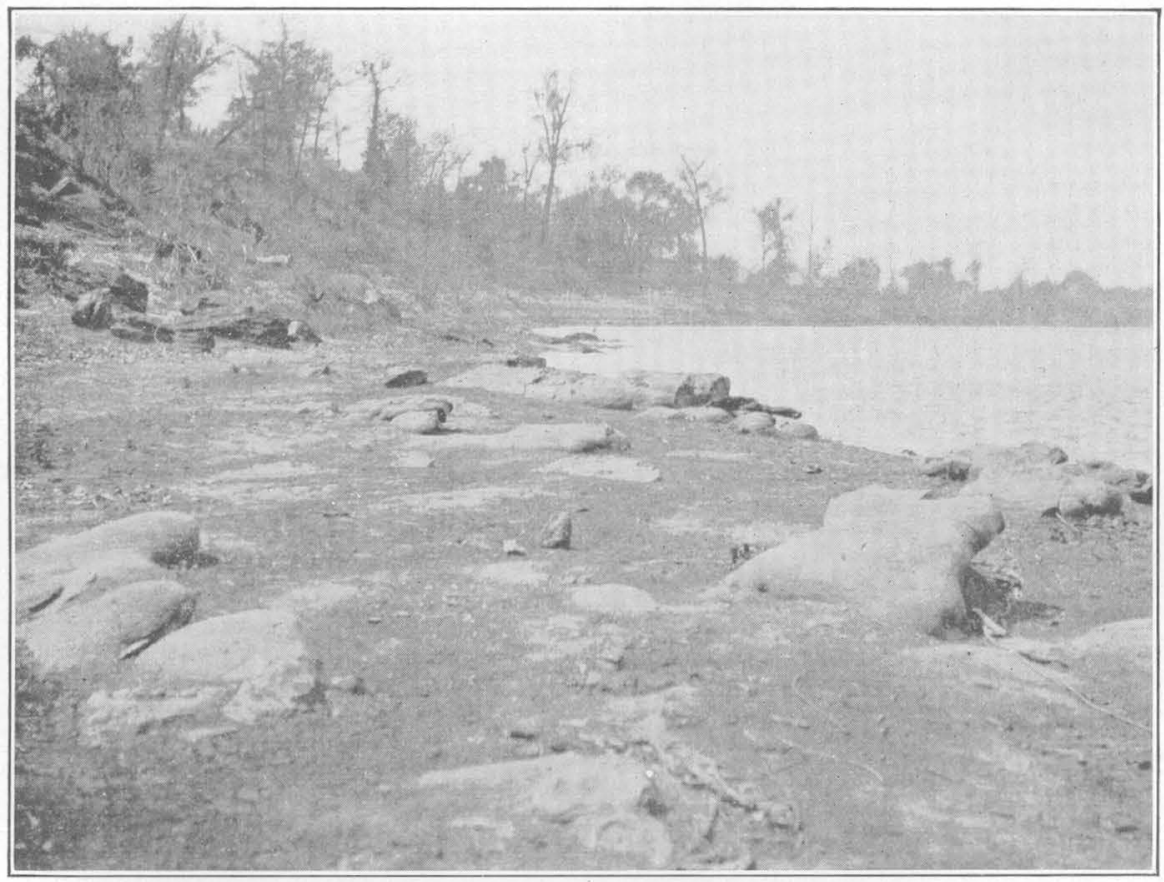

$B$. TUFFACEOUS SAND OF THE WOODBINE FORMATION, PARTLY INDURATED TO CONCRETIONARY MASSES, NEAR THE UPPER END OF HYATTS BLUFF, RED RIVER, FANNIN COUNTY, TEX. 
mineral that is normally derived from feldspathic material, and small proportions of augite, hornblende, zircon, and tourmaline that are characteristic of the volcanic rocks are present. It is therefore probable that the kaolin in these beds was derived from feldspathic volcanic material that had been reworked and deposited.

\section{PERIDOTITE TUFF (?)}

The lower beds of the Tokio formation on the Riley place and on the Twin Knobs, near Murfreesboro, Pike County, Ark., consist in large part of altered serpentine grains and peridotite fragments. Although the beds are water-laid, showing lamination and pronounced cross bedding, the igneous material may have been ejected into the air from the near-by vents and then fallen to or near its present position. There is, however, no evidence yet known that would preclude the derivation of the material from adjacent peridotite exposures by erosion.

Peridotite tuff (?) is present in small areas around the masses of peridotite, though it appears to be absent at two localities where exposures show the Tokio formation resting directly upon the peridotite.

\section{CHEMICAL RELATIONS OF VOLCANIC ROCKS OF ARKANSAS}

The following analyses show the chemical composition of the volcanic rocks and their relations to other igneous rocks of Arkansas:

Analyses of volcanic rocks of Arkansas and related intrusive rocks

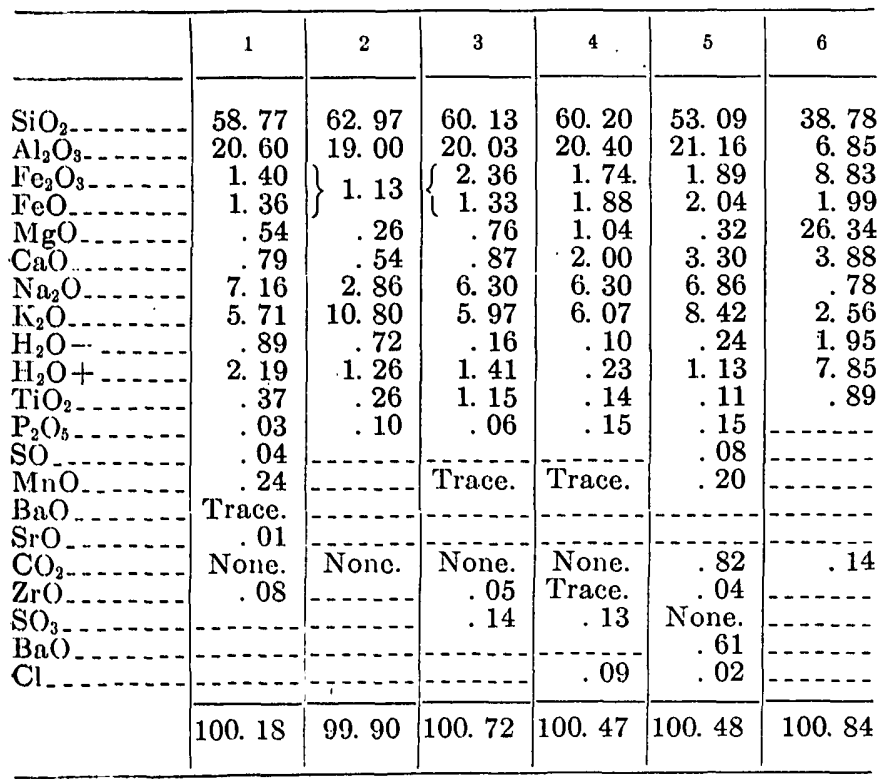

1. Phonolite boulder, Mine Creek, Howard County, Ark. George Steiger, analyst.

2. Orthoclase trachyte, Coleman Creek, Howard County, Ark. George Steiger, analyst.

3. Foyaite, Braddock's quarry, Fourche Mountain, Little Rock, Ark. H. S. Washington, analyst. Washington, H. S.,
The foyaite-ijolite series of Magnet Cove [Ark.]: Jour. Geology, vol. 9, pp. 609, 611, 1901.

4. Pulaskite, Fourche Mountain, Little Rock, Ark. H. S. Washington, analyst. Idem.

5. Foyaite, Diamond Joe quarry, Magnet Cove, Ark. H. S. Washington, analyst. Idem.

6. Peridotite (probably hypabyssal) from Prairie Creek area, Ark. R. N. Brackett, analyst. Williams, J. F., Igneous rocks of Arkansas: Arkansas Geol. Survey Ann. Rept. for 1890, p. $383,1891$.

Norms of volcanic rocks of Arkansas and related intrusive rocks, [The numbers correspond to those in the preceding table; anglysis 6 represents an altered rock, and no norm has been calculated]

\begin{tabular}{|c|c|c|c|c|c|}
\hline & 1 & 2 & 3 a & $4^{\circ}$ & 50 \\
\hline $\begin{array}{l}\text { Q- } \\
\text { Z }\end{array}$ & 0.24 & 3. 60 & & & \\
\hline & 1. 10 & 1. 80 & 1. 53 & & \\
\hline & 33. 92 & 63.94 & 35.58 & 36. 14 & 49. 48 \\
\hline$a b \ldots$ & 44.44 & 24. 10 & 49. 26 & 42.44 & S. 12 \\
\hline an... & 3. 89 & 1. 95 & 4. 45 & 9.17 & 2. 22 \\
\hline ne.. & 8. 80 & -- & 1. 99 & 5. 96 & 27. 12 \\
\hline cc- - & $\ldots-\ldots$ & $\cdots$ & $\ldots \ldots$ & $-\cdots$ & \\
\hline Sal_ & 92. 49 & 95. 39 & 92.81 & 93. 71 & 88. 74 \\
\hline $\mathrm{di}_{-}$ & & & $\ldots$ & -2 & 5. 45 \\
\hline $\begin{array}{l}\text { wo } \\
\text { hy }\end{array}$ & & 1.13 & & & .81 \\
\hline ol $\ldots$ & 1. $80^{-}$ & 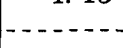 & 1. 33 & 3.15 & \\
\hline $\begin{array}{l}\mathrm{mt}_{2} \\
\mathrm{hm}\end{array}$ & 2. 09 & . - & $\begin{array}{r}.93 \\
1.76\end{array}$ & 2.55 & 2. 78 \\
\hline il & .74 & .46 & 2. 13 & .30 & .15 \\
\hline ap....... & & .34 & & .34 & \\
\hline Fem & 4. 65 & 1. 93 & 6. 15 & 6. 34 & 9. 53 \\
\hline
\end{tabular}

- Washington, H. S., U. S. Geol. Surrey Prof. Paper 99, pp. 271, 287, 305, 1917.
1. I.(4) 5 . $1^{\prime \prime} .^{\prime} 4$
2. I.5.1.2.
4. I" I $^{\prime \prime} \prime \prime 2.3(4)$.
3. I.5.1".3(4).
5. I(II) $\cdot \dot{6}^{\prime \prime} \cdot 1.3$.

The analyses just given and the norms calculated from them show that two distinct types of rock have contributed material to the Arkansas tuffs. The most striking quality that these rocks have in common is the high percentage of the alkalies and the low percentage of iron and magnesia that go to produce ferromagnesian minerals. The phonolite boulder from Mine Creek, Howard County, Ark. (analysis 1), contains 92.49 per cent of salic minerals, of which 78.46 per cent consists of alkalic feldspars. It is low in femic minerals, low in anorthite, and very low in magnesium. It is therefore an alkalic phonolite rather rich in potassium, and, as would be expected in a rock of this type, the structure is trachytic. In normative composition it is very similar to the foyaite from Braddock's quarry, Fourche Mountain, Little Rock, Ark., and to the pulaskite from Fourche Mountain.

The rock from Coleman Creek, Howard County, Ark. (analysis 2), has a very unusual chemical composition. Only two rocks that fall in the groups I.5.1.1 and I.5.1.2 of the quantitative system are listed by Washington. ${ }^{18}$ One of these is orthoclasite, an orthoclase-

19 Washington, H. S., U. S. Geol. Survey Prof. Paper 99, p. 269, 1917.

$$
100874^{\circ}-29-13
$$


rich dike rock from Alaska, and the other a pegmatite. The rock from Coleman Creek is closely related to the rock from Fourche Mountain (analysis 3) but is very much higher in potassium. With nearly 64 per cent of orthoclase, 88 per cent of alkalic feldspar, and only 1.93 per cent of femic minerals in the norm, it constitutes a new rock type for Arkansas and a type that has not heretofore been reported among volcanic rocks. It can be best described as an orthoclase trachyte.

/ The analysis of the massive hypabyssal peridotite is given to show the dissimilarity between the diamondbearing rock of Pike County, Ark., and the volcanic tuffs of the same area.

\section{AGE OF THE VOLCANIC ROCKS}

The Woodbine and Tokio formations, both of which contain water-laid volcanic rocks, have yielded fossils from which the age of the formations may be determined. Fossil plants have been obtained from the Woodbine formation on Mine Creek 3 miles north of Nashville, Ark., and from the Tokio formation in the "Big" railroad cut, $21 / 2$ miles east of Tokio, Ark., and in the Adams kaolin pits, in sec. 24, T. 8 S., R. 25 W., 5 miles east-southeast of Murfreesboro, Ark. The plants at the Adams pits occur in a 5 -foot bed of kaolin which is probably altered volcanic material; the plants on Mine Creek are in a lens of clay in a thick bed of tuff; and the plants at the railroad cut are in a dark gumbo clay that is overlain by sand and lightcolored clay.

No fossil invertebrates have been found in the Woodbine formation in Arkansas, but the Tokio formation has yielded small collections from five or six localities, mostly of poorly preserved prints and molds.

The fossil plants from the Woodbine and Tokio formations in Arkansas have been studied by Berry. ${ }^{19}$ Also a fossil flora composed of 43 species from the Woodbine sand at Arthurs Bluff, on Red River in Lamar County, Tex., has been studied by Berry. ${ }^{20}$ The fossil plants there occur in coarse sandstone containing a considerable percentage of tuffaceous material and in more or less sandy cross-bedded clay interbedded with and overlying the sandstone. Berry says:

I can therefore only state the well-known fact that the Woodbine and Bingen formations are at least partly contemporaneous. I am of the opinion, which is based on the range of the Woodbine plants in other formations, that Arthurs Bluff is approximately on the boundary between the lower and upper members of the Bingen as recognized by Miser in Arkansas in the specific area where he collected the plants.

Since the publication of Berry's papers on the fossil floras of the "Bingen formation" of Arkansas and the Woodbine sand at Arthurs Bluff in Texas much has been learned in regard to the age and stratigraphic

10 Berry, E. W., Contributions to the Mesozoic flora of the Atlantic Coastal Plain, XII-Arkansas: Torrey Bot. Club Bull. 44, pp. 167-190, 1917.

${ }^{20}$ Berry, E. W., The flora of the Woodbine sand at Arthurs Bluff, Texas: U. S. Geol. Survey Prof, Paper 129, pp. 153-181, 1922, relations of these and other formations of the Gulf series in Arkansas and northeastern Texas. Miser and Purdue ${ }^{21}$ in 1919 divided the "Bingen sand" of Veatch, in Howard and Pike Counties, Ark., into the lower or main part of the formation and an upper "Tokio sand member." The distribution of the "Tokio sand member" as represented on the map accompanying the paper cited shows that it overlaps the main part of the "Bingen" and finally conceals the "Bingen" completely from west to east. The unconformity beneath the gravel bed at the base of the Tokio formation of the present report has since been traced by Dane southwestward as far as Little River, where it is concealed by the river alluvium. From northeast to southwest the Tokio, according to Dane, ${ }^{22}$ becomes interstratified with beds of clay of increasing thickness, until in Sevier County the clay predominates over the sand.

The lower part of the "Bingen sand" of Veatch contains the thickest beds of volcanic tuff already mentioned, and thin beds of volcanic material are present in the overlying Tokio formation. The beds of volcanic tuff of the lower part of the "Bingen sand" have been traced westward from Arkansas through McCurtain, Choctaw, and Bryan Counties, Okla., and through the northern parts of Red River, Lamar, and Fannin Counties, Tex., where they form a continuous and characteristic deposit connecting directly with the upper part of the Woodbine sand. The tuffaceous beds are interbedded with the fossil plant bearing beds at Arthurs Bluff. In Lamar and Fannin Counties the volcanic tuffs have been definitely identified beneath the Eagle Ford clay, showing that the lower part of the "Bingen" is in reality the eastward extension of the upper part of the Woodbine sand.

The Tokio in Arkansas has been found by Dane to contain fossils at several stratigraphic positions, the lowest within 70 feet of the base, which according to Stephenson indicate with reasonable certainty that this division is younger than the Eagle Ford clay. Inasmuch as the lower part of the "Bingen"- that is, the Woodbine sand-passes beneath the Eagle Ford in Texas, and the upper part of the "Bingen"- that is, the Tokio formation-is younger than the Eagle Ford, it follows that the Eagle Ford is represented in Arkansas by the unconformity between the Woodbine and Tokio.

\section{MANNER OF DEPOSITION OF VOLCANIC MATERIALS}

The lithic tuffs of the Woodbine formation were water-laid, as is shown by the rounded pebbles of large and small sizes, the assortment of the larger pebbles into lenses at some places, the local occurrence of glauconite, and conspicuous cross-bedding, which

${ }^{21}$ Miser, Hugh D., and Purdue, A. H., Gravel deposits of the Caddo Gap and De Queen quadrangles, Ark.: U. S. Geol. Survey Bull. 690, pp. 22-24, 1918. 22 Dane, C. H., U. S. Geol. Survey press notice, Sept. 10, 1926. 
is revealed in all exposures. Yet in spite of the waterlaid character of these tuffs the orthoclase, augite, titanite, and spinels found in them, especially in the Nashville area, show very perfect crystal faces with little evidence of attrition.

The pumiceous orthoclase trachyte tuffs of the Woodbine formation display little or no evidence of bedding, but some of them contain leaf fragments suggesting that they, like the lithic tuffs. were deposited in water.

The tuftaceous sand of the Woodbine contains invcrtebrate fossils in some of the exposures in Oklahoma and Texas. The fossils together with the character of the sand indicate that the Woodbine was there deposited in marine and brackish waters.

The cross-bedding and assortment of the materials in peridotite tuff of the Tolkio formation indicate that the tuff was water-laid. The kaolin beds that appear to be derived from material of volcanic origin in the Tolkio formation were also water-laid, as is shown by the occurrence of horizontal laminae, an occasional grain of glauconite, and fossil plant leaves and stems lying parallel with the laminae.

\section{VOLCANIC VENTS OF CRETACEOUS AGE IN ARKANSAS, OKLAHOMA, AND NORTHEASTERN TEXAS}

The location of the vents that supplied the volcanic material in the Woodbine and Tokio formations may be inferred from the different kinds of volcanic material, from the thickness of the water-laid volcanic deposits, from their distribution, and from their change in character from place to place.

Of the known deposits of tuff in Texas, Oklahoma, and Arkansas, the thickest lie in Howard, Pike, and Sovior Counties, Ark. This fact, combined with the woll known occurrence of volcanic activity at Murfreesboro, Piko County, suggests that the vent or vents through which the enormous quantity of tuff and ash in southwestern Arkansas, southeastern Oklahoma, and northeastern Texas was ejected were situated in these three counties. The areas of Lower Cretaceous and older rocks in these and adjoining counties have been carefully studied by many geologists, but thus far no volcanic vents active in Cretaceous time except the peridotite vents near Murfreesboro have been discovcred. If the Cretaceous vents supplying the other linds of volcanic material were situated in the southern parts of the counties they are now concealed by beds of Upper Cretaceous and Quaternary age.

The volcanic center a few miles southeast of Murfreesboro, Ark., consisted of three or more volcanoes, here named the Murfreesboro volcanoes. (See fig. 18 and pl. 19.) The rocks that fill these old vents are exposed. Another vent that erupted volcanic material of a trachytic type was apparently a few miles northwest of Nashville, Ark., and a second was apparently half to three-quarters of a mile south of Lockesburg,
Ark. These two vents are here named the Nashville and Lockesburg volcanoes. They supplied the tuffaceous material in the Woodbine formation. Neither of the vents is exposed. How many other centers, if any, there may have been in southwestern Arkansas, southeastern Oklahoma, and northeastern Texas is not known. The exhaustive studies by different geologists of the syenites and related types of igneous rocks near central Arkansas have not suggested to them that the intrusion of these rocks was accompanied by volcanic explosions. The evidence for the assumption that volcanic vents were located near Lockesburg and Nashville is given in the several succeeding paragraphs.

The location of the three volcanoes mentioned above, as well as the location of distant volcanoes of Cretaceous age in these and adjacent States, is shown on Figure 18. The Monroe, Thrall, and Lytton Springs volcanoes were discovered by means of deep oil and gas wells.

The peridotite material at the base of the Tokio formation near Murfreesboro, Ark., is believed to be peridotite tuff. Its occurrence near the Murfreesboro volcanoes indicates that they were its source. The necks of these volcanoes are filled with three kinds of peridotite-porphyritic rock, breccia, and tuff. The breccia is diamond bearing and has yielded diamonds in small commercial quantities. The volcanic activity apparently took place in early Upper Cretaceous time, as is indicated by the upward extension of the necks through beds of the Trinity formation (Lower Cretaceous) and by the occurrence of deposits of waterlaid peridotite material (peridotite tuff?) in the lower part of the Tokio formation (Upper Cretaceous).

The Murfreesboro volcanoes did not yield more than a small quantity of ejected material to the thick, widespread deposits of volcanic rocks in the Woodbine and Tokio formations, for no positive identification of peridotitic material has been made in the formations except at localities near Murfreesboro.

The volcanic rocks represented in the Woodbine and Tokio formations other than peridotitic material include two kinds whose sources will be considered separately. One kind is an orthoclase trachyte, characterized by pumice now largely altered to bentonite, and the other is characterized by beds of lithic phonolite pellets.

The fragments of orthoclase trachyte associated with the pumice tuffs are not rounded, and the crystal grains are all very sharply euhedral or angular where fractured. Some of the pumice beds contain no foreign detrital material of any kind, even where the beds above and below contain large proportions. Much of the pumice was composed of lenticular vesicles bordered by exceedingly thin walls that made it an unusually fragile material. There was no sort.. ing or sizing of pumice, and sharply angular frag- 
ments are discernible in every thin section examined. The fragile nature of the pumice and its relations seem to preclude any extensive transportation. The purest pumice and trachyte tuffs are found on Coleman and Pleasant Valley Creeks (fig.17), and the tuffs become less pure with distance from that locality. These circumstances seem to indicate rather clearly that the volcanic centers that supplied the pumice and trachyte tuffs were situated not more than a few miles from a point about 3 miles northwest of Nashville, Ark.

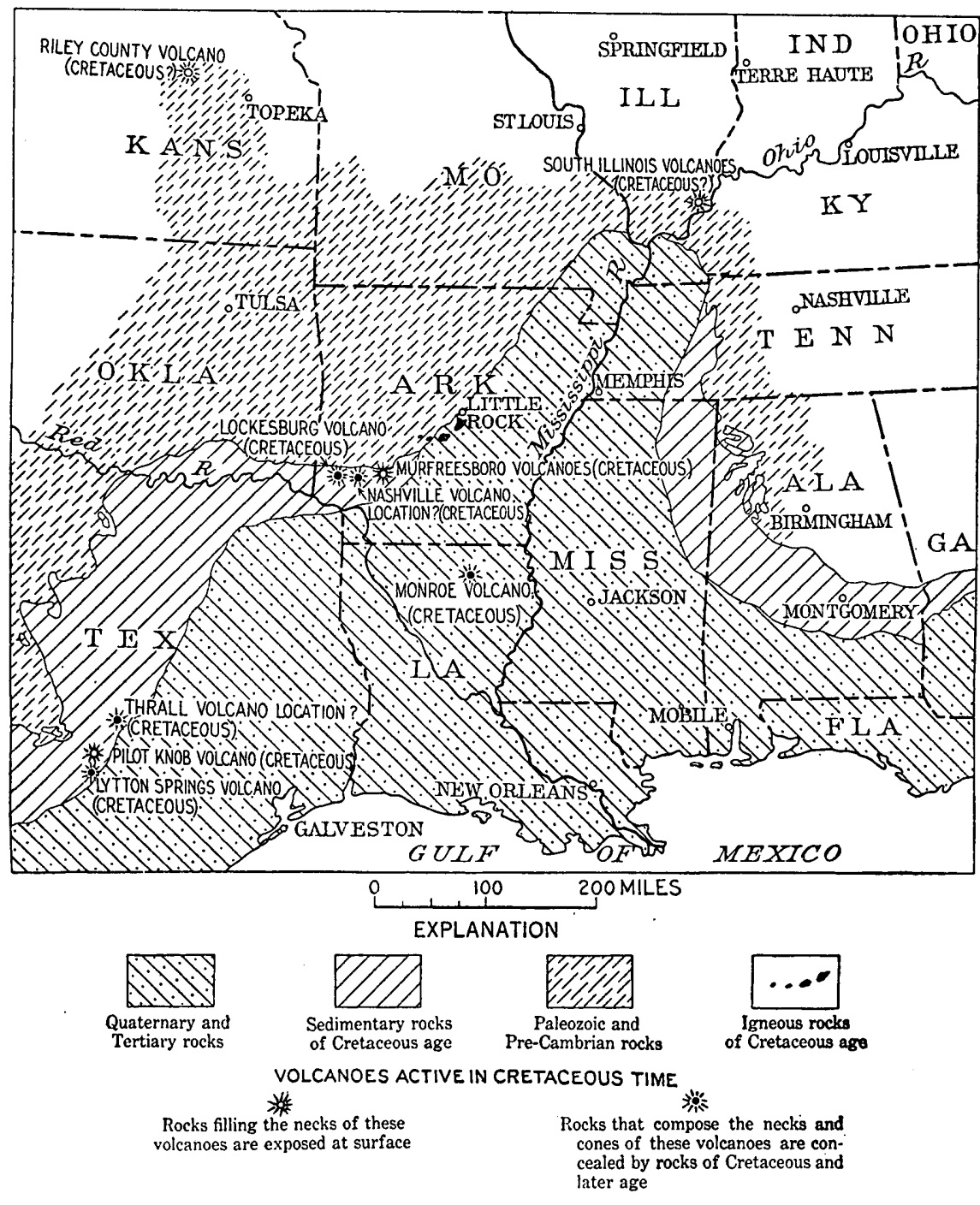

FIGURE 18.-Map of Arkansas and adjacent States showing the location of volcanoes that were active in Cretaceous time and the exposures of igneous rocks of Cretaceous age show crystal faces but are more rounded than in the Nashville area. Fresh augite is very rare but appears to have been abundant prior to replacement by calcite; magnetite, spinel, and other minerals that resist replacement are just as abundant as near Nashville. Pyrite and siderite have developed, augite has been replaced by calcite, and glauconite has formed films around and replaced mineral and rock grains.

These results make it seem possible that the easternmost parts of the tuffaceous beds of the phonolite type were nearest to the volcanic center that supplied the material. On the other hand, the cobbles of phonolite found on Mine Creek near Nashville, Ark. (fig. 17), were exceedingly well rounded and possibly somewhat weathered before they became incorporated in the tuffs and associated gravel beds. The small rock pellets that are characteristic material of the phonolite tuffs and sands are rounded and rather well sorted and more or less mixed with quartz and novaculite grains. This suggests that the phonolite material had been transported some distance, even in the Arkansas part of the region, though it could hardly have been carried by streams from the areas of igneous rocks near the center of Arkansas, the nearest of which is between 50 and 60 miles northeast of Murfreesboro. The evidence in favor of transportation is somewhat opposed by the euhedral shape and lack of rounding of the phenocrysts from the phonolite tuffs. On the whole, however, there seems to be no evidence that excludes considerable transportation of the phonolite volcanic material or that suggests a very exact location of the volcanic center or centers from which it came. Probably, however, the eastern tuff beds were nearer the source of supply than those in the Texas-Oklahoma region, where there is greater mixing with other materials and a greater rounding of mineral grains.

That a volcanic center was situated in the vicinity of Lockesburg, Sevier County, Ark., is suggested by natural phenomena there. Three-quarters of a mile south of Lockesburg broken and bent beds of the Trinity are revealed in a small exposure by the roadside. $^{23}$ No post-Cretaceous faulting and certainly no close Cretaceous folding has affected the Trinity at any other place in Arkansas, Oklahoma, or the adjacent part of Texas with which the writers are familar. The

23 Dane, C. H., letter of Jan. 20, 1926. 
steep dips and fractures in the Trinity are perhaps attributable to displacement in connection with volcanic activity. Weight is added to this suggestion by the occurrence of many large angular blocks of Paleozoic sandstone at the locality three-quarters of a mile south of Lockesburg. The blocks, measuring as much as 15 feet in length, 4 feet in width, and 3 feet in thickness, could not have been transported very far by streams that deposited the known gravel beds of Cretaceous age in Arkansas. ${ }^{23}$ The nearest exposures of Paleozoic sandstone are in the Ouachita Mountains 10 miles north of Lockesburg. Moreover, the great abundance of the sandstone blocks at the Lockesburg locality indicates that they were probably not transported from the Ouachita Mountains. Their source was thus apparently near by. Possibly they came from a high ridge of Paleozoic sandstone that may have extended upward entirely through the Trinity, about 1,000 fect thick, or from blocks of sandstone brought upward by volcanic explosions. Ridges of so great height on the Cretaceous floor are not known in Arkansas, though ridges several hundred feet high are known near Spencerville, Choctaw County, Okla. At the volcanic neck near Murfrcesboro, Ark., on which the Ozark, Mauney, and Arkansas diamond mines are located, there are masses of Paleozoic quartzite hundreds of feet in their longest dimension. These have all been lifted upward by the forces accompanying the volcanic activity, and it seems probable that the same explanation applies to the tilted Paleozoic blocks near Lockesburg.

\section{WIDESPREAD VOLCANIC ACTIVITY DURING CRETA-} CEOUS PERIOD 24

Volcanic materials are widespread in the Woodbine formation, not only on the outcrop but in the deposits away from the outcrop, also in equivalent and overlying beds of Upper Cretaceous age. Furthermore, they are present not only in Arkansas and Oklahoma but also in Louisiana, Texas, and Alabama. The occurrences are briefly mentioned below.

Bentonite has been found in the "Bingen formation" (Woodbine and Tokio formations) in wells in Union County, Ark., as identified from samples sent to the Geological Survey by H. D. Easton.

Bentonite occurs in Louisiana in beds that appear to be the equivalent of the Arkadelphia clay or the Marlbrook marl (Upper Cretaceous), which are younger than the Woodbine and Tolkio formations. ${ }^{25}$

\footnotetext{
2s Dane, C. H., personal communication, Jan. 20, 1926.
}

it Since the present paper was written a comprehensive report, by J. T. Lonsdale, on the igneous rocks of the Balcones fault region of Texas, was issued Nov. 22, 1927, as Bulletin 2744, by the Bureau of Economic Geology of the University of Texas. Lonsdalo describes not only the exposed igneous rocks but also those that have been found in wclls. Brief references are made in the present paper to occurrences of of igneous rocks in Texas. The rocks of all the occurrences cited, as well as others, are described by Lonsdale. He describes their form, distribution, and petrographic character and also discusses the age and nature of the igneous activity.

${ }^{26}$ Bramlette, M. N., Bentonite in the Upper Cretaceous of Louisiana: Am. Assoc. Petrolcum Gcologists Bull,, vol. S, pp. 342-344, 1924.
Bentonite of exceptional purity which shows very perfect volcanic-ash structure occurs in the Eutaw formation, of Upper Cretaceous age, near Montgomery, Ala. Material from this deposit was collected by Doctor Carver, of the Tuskegee Institute, and submitted to Clarence S. Ross by Henry M. Payne for identification. The age of the bed is inferred by $\mathrm{L} . \mathrm{W}$. Stephenson ${ }^{26}$ from the geographic location of the bentonite occurrence. Material from the same deposit has been submitted to the United States Geological Survey by $\mathrm{E}$. M. Graves, of Montgomery. ${ }^{26}$

An unusually pure bentonite near Aberdeen, Monroe County, Miss., is reported by the State geologist ${ }^{27}$ to be part of the Eutaw formation. The Eutaw formation is correlated by Berry ${ }^{28}$ with the Tokio formation ("upper Bingen").

Volcanic ash is found in the Eagle Ford clay in wells in northeastern Texas. $^{29}$ This clay is regarded by Stephenson as occupying part of the hiatus represented by the unconformity between the Woodbine and Tokio formations.

Thin layers of bentonite reaching a maximum thickness of 1.5 feet, interbedded with shaly clay and platy limestone, have been observed by Stephenson and others in the lower part of the Eagle Ford clay in Texas as follows: In the vicinity of Austin, Travis County; ${ }^{30}$ northeast of Georgetown, Williamson County; between Belton and Temple, Bell County; at several places along the strike of the formation in McLennan County; ${ }^{31}$ near Grand Prairie, Dallas County; ${ }^{32}$ and west of Pottshoro, Grayson County. These localities may prove to be parts of a continuous zone in the lower part of the Eagle Ford clay extending at least from Travis County to Grayson County.

Pilot Knob, 8 miles southeast of Austin, Tex., (fig. 18), marks the site of an ancient volcanic eruption, which probably took place late in Austin time and early in Taylor time. ${ }^{33}$ Beds of tuff that are related to the central mass extend outward from it for 6 miles. The typical Austin chalk, according to Stephenson, is apparently represented by the Tokio formation. The lower part of the typical Taylor marl, also according to Stephenson, ${ }^{34}$ is apparently equivalent to the Brownstown marl, which overlies the Tokio formation. If these correlations are correct,

${ }^{20}$ Stephenson, L. W., The Mesozoic rocks, in Geology of Alabama: Alabama Geol. Survey Special Rept. 14, p. 236, 1926.

${ }^{27}$ Lowe, E. N., personal communication.

${ }_{28}$ Berry, E. W., Contributions to the Mesozoic flora of the Atlantic Coastal Plain, XII-Arkansas; Torrey Bot. Club Bull., vol. 44, pp. 167-190, 1917.

29 Waite, V. V., oral communication to H. D. Miser.

${ }^{80}$ Dr. J. A. Udden (oral communication) has recognized bentonitic clay in Eaglo Ford shale, in exposures on a small southern tributary of Colorado River, just south of Austin, Tex.

"11 Adkins, W. S., Texas Univ. Bull. 2340, p. 107, 1923.

${ }^{2}$ Stanton, T. W, oral communication.

${ }^{33}$ Hill, R. T., and Kemp, J. F., Pilot Knob, a marine Cretaceous volcano: Am Geologist, vol. 6, pp. 286-294, 1890. Deussen, Alexander, Geology of the Coasta Plain of Texas west of Brazos River: U. S. Geol. Survey Prof. Paper 126, p. 120, 1924.

3 Stephenson, L. W., A contribution to the geology of northeastern Texas and southern Oklahoma: U, S, Geol, Survey Prof. Paper 120, p. 154, 1919. 
the eruption at Pilot Knob occurred during and soon after Tokio time. Intrusive igneous rocks are present farther southwest in Texas, particularly in Uvalde County. The volcanic activity in that county took place in Tertiary time. ${ }^{35}$

A buried sill of decomposed basalt, or possibly a bed of volcanic tuff, occurs in the Taylor marl near Thrall, Williamson County, Tex. ${ }^{36}$ (See fig. 18.) As the lower part of the Taylor marl is equivalent to the Brownstown marl, the sill of basalt or bed of tuff may have been formed soon after Tokio time. Concerning the body of igneous rock Deussen ${ }^{37}$ says:

The body is evidently either a sill connected with some near-by volcanic neck or a tuff similar to those exposed near Austin, deposited by a submarine volcano that was active in this vicinity in early Taylor time. In any event the rock is closely related structurally and historically to the Pilot Knob disturbance near Austin.

At Lytton Springs, Caldwell County, Tex., a body of igneous rock ${ }^{38}$ has been found in deep wells to project upward through the Austin chalk into the Taylor marl. The rock, which is now largely serpentine and chlorite, was originally volcanic ash, lava, and intrusive basalt and probably represents an old burjed. volcanic cone. The igneous rock here, like the serpentine rock at Thrall, yields oil in commercial quantities.

Beds of bentonite occur in the Navarro formation at a locality $31 / 2$ miles northwest of Macdona, Bexar County, Tex. The purer layers retain perfectly the characteristic structure of the glassy volcanic tuffs from which the bentonite was derived. Specimens collected by J. A. Udden and M. I. Goldman were examined. This deposit, previously referred to the Taylor marl, is believed by Stephenson to belong to the Navarro formation.

A succession of volcanic tuffs and flows underlies a part of the Monroe gas field of Louisiana. It is 1,100 to 1,200 feet thick and "seems to include the interval between the Nacatoch, Marlbrook, or Annona, and the Washita (of Comanche age)." ${ }^{39}$ The differences in the thickness of the tuffs and flows and their distribution strongly suggest that they form a part of a volcanic cone which is buried in Cretaceous sediments. (See fig. 18). The inclosing sediments above and those below, being both of Cretaceous age, indicate that the volcano was active in Cretaceous time.

Volcanic tuff from the Prothro salt dome, in T. 14 N., R. 6 W., Bienville Parish, La., is identical in appearance and composition with some of the lithic tuffs in

\footnotetext{
${ }^{36}$ Deussen, Alexander, op. cit., p. 121

${ }^{36}$ Udden, J. A., Oil in an igneous rock: Econ. Geology, vol. 10, pp. 582-585, 1915. ${ }^{37}$ Deussen, Alexander, op. cit., p. 120.

${ }^{38}$ Bybee, H. P., and Short, R. T., The Lytton Springs oil field: Texas Univ. Bull. 2539, Oct. 15, 1925. Collingwood, D. M., and Rettger, R. E., The Lytton Springs oil field, Caldwell County, Tex.: Am. Assoc. Petroleum Geologists Bull., vol. 10 , pp. 953-975, 1926.

${ }^{39}$ Bramlette, M. N., Volcanic rocks in the Cretaceous of Louisiana: Am. Assoc Petroleum Geologists Bull., vol. 8, pp. 344-346, 1924. Spooner, W. C., and Bell, H. W. The Monroe gas field: Louisiana Dept. Conservation Bull. 12, pp. 5-6, figs. 1, 2, 1925. Easton, H. D., Oil and Gas Journal, Mar. 24 and Oct. 13, 1927.
}

the Woodbine formation of Arkansas and Oklahoma; but, according to Stephenson, the fossils from the tuff at Prothro dome indicate that it is younger than the Eagle Ford clay and is probably of the age of the Tokio formation and the typical Austin chalk. The tuff, according to J.P.D. Hull, ${ }^{40}$ who examined the locality in 1922 , and also according to W. C. Spooner, ${ }^{41}$ who has recently examined the locality, is exposed in almost vertical ledges 110 feet in total thickness. Mr. Spooner says he has found an outcrop of the same kind of rock in beds of the same age in the Rayburn salt dome, in T. 15 N., R. 5 W., Bienville Parish, La.

The tuffaceous sand of the Prothro dome contains phonolite with the same unusual and significant composition that characterizes the phonolite tuffs of Arkansas, and trachyte and pumice of the Arkansas type are present in minor quantities. Also the entire list of minerals associated with the tuffs is the same. The volcanic rocks in the two areas thus have the same lithologic character. Siderite has formed, calcite has replaced augite, and an unusual type of glauconite has been deposited in films around and has replaced augite crystals and phonolite grains in both areas.

Thus in the Prothro dome and in Arkansas, Oklahoma, and Texas the volcanic materials are the same (see table on p. 194), their relations are the same, and very peculiar and unusual secondary replacement processes affected the beds in both regions in the same way. The peculiar lithologic characters suggest in themselves that the beds in the Prothro dome represent the same formation that crops out in Arkansas, but the fossils discussed by Stephenson on page 200 seem to afford conclusive evidence that the Prothro dome and Woodbine beds are not of the same age.

The volcanic activity that produced the peridotite of Pike County and the nephelite syenites and associated types in other parts of Arkansas probably accompanied the down-warping of the Mississippi embaymentin Upper Cretaceous time. The tuff and ash falls in the Woodbine and Tokio formations of southeastern Oklahoma and Arkansas probably took place at.this time. As has been pointed out by Branner, ${ }^{42}$ the igneous rocks of Arkansas occur near and parallel with the old Cretaceous-Tertiary shore line, which extended northeastward across the State. He believed that this shore line was affected by faulting or other weakness and that the igneous rocks of Arkansas had some possible connection with this line of disturbance. The similarity of the peridotite and lamprophyre dikes of western Kentucky and southern Illinois and the peridotite breccia of Riley County, Kans. ${ }^{43}$ (fig. 18),

10 Letter dated Aug. 1, 1924. See also Hull, J. P. D., Prothro salt dome, Bienville Parish, La.: Am. Assoc. Petroleum Geologists Bull., vol. 9, pp. 905-906, 1925.

\$1 Letter dated Aug. 2, 1924; also Interior salt domes of Louisiana: Am. Assoc. Petroleum Geologists Bull., vol. 10, pp. 229-230, 248, 262-263, 1926.

42 Branner, J. C., The former extension of the Appalachians across Mississippi, Louisiana, and Texas: Am. Jour. Sci., 4th ser., vol. 4, p. 365, 1897.

${ }^{43}$ Moore, R. C., and Haynes, W. P., An outcrop of basic igneous rock in Kansas: Am. Assoc. Petroleum Geologists Bull., vol. 4, pp. 183-187, 1920. 
suggests that the intrusion of the peridotite in those States occurred during Upper Cretaceous time. Although this is a mere suggestion, the writers know of no facts that would militate against this view. Plugs of volcanic breccia of acidic rocks occur in the same region as the dikes of southern Illinois (fig. 18) and "may represent an explosive phase of the region's igneous phenomena." 44

\section{VOLCANIC ACTIVITY IN GULF COASTAL PLAIN AND ADJOINING REGION IN PALEOZOIC AND TERTIARY TIME}

Volcanic activity that affected the Gulf Coastal Plain and the adjoining country has taken place not only in the Upper Cretaceous epoch but at several other times. Bentonite occurs in the Ordovician rocks of Kentucky, Tennessee, and Alabama. ${ }^{45}$ Bentonite and slightly metamorphosed tuff also occur in Ordovician rocks in Virginia ${ }^{46}$ and Pennsylvania. ${ }^{47}$ Volcanic ash is reported by C. W. Honess in the Missouri Mountain slate (Silurian), in McCurtain County, Okla ${ }^{48}$ Also volcanic ash and breccia are reported by Honess from two horizons in the Arkansas novaculite of Devonian age in McCurtain County, Okla., ${ }^{49}$ and he suggests that at least some of the Arkansas novaculite is silicified and devitrified volcanic ash. Volcanic tuff occurs in a bed 90 to 100 feet thick and in several thinner beds in the Stanley shale (Carboniferous) in Polk County, Ark., and McCurtain County, Okla. ${ }^{50}$

Beds of Tertiary bentonite of different ages are reported by Henry M. Payne ${ }^{51}$ to occur at several localities in Mississippi and Alabama. The age of the beds is inferred by C. W. Cooke from the geographic location. The localities together with the age of the bentonite beds are as follows: In beds of probable Miocene age on the outskirts of Mobile, Ala.; in the Clayton formation, of Midway (Eocene) age, at Houlka, Chickasaw County, Miss.; in the Porters Creek clay, of Midway (Eocene) age, west of Woodland, Chicka-

4 Currier, L. W., Igneous rocks [of Hardin County, Ill.]: Minois Geol. Survey Bull. 41, pp. 237-244, 1920.

is Nelson, W. A., Volcanic ash bed in the Ordovician of Tennessee, Kentucky, and Alabama: Gool. Soc. America Bull., vol. 33, pp. 605-615, $1922 . \quad$ Butts, Charles, Tho Paleozoic rocks, in Geology of Alabama: Alabama Geol. Survey Special Rept. 14, pp. 113-114, 131-133, 1926; U. S. Gcol. Survey Gcol. Atlas. Bessemer-Vandiver follo (No. 221), pp. 7, 16, pls. 10,17, 1927.

so Taber, Stephen, Geology of the gold beit in the James River basin of Virginia: Virginia Geol. Survey Bull, 7, p. 43, 1913. Powell, S. L., letter dated March 24, 1025. Nelson, W. A., Volcanic ash deposit in the Ordovician of Virginia: Geol. Soc. A merica Bull., vol. 37, pp. 149-150, 1926. Giles, A. W., The origin and occurrence in Rockbridge County, Va., of so-called "bentonite": Jour. Geology, vol. 35, pp. 527-541, 1927. Ross, C. S., Palcozoic volcanic materials and criteria for their zecognition: Am. Assoc. Petroleum Geologists Bull., vol. 12, pp. 143-164, 1928.

7 Bonine, C. A., Researches in sedimentation in 1925 and 1926, pp. 4-5, National Rosearch Council, 1926. Stose, G. W., and Jonas, A. I., Ordovician shale and associated lava in southeastern Pennsylvania: Geol. Sce. America Bull., vol. 38, pp. 505-536, 1927.

48 Honess, C. W., Geology of the southern Ouachita Mountains of Oklahoma: Oklahoma Geol. Survoy Bull. 32, pp. 107-109, 1923.

$10 \mathrm{Jdem}, \mathrm{pp} .121-130$.

so Miser, II. D., Mississippian tuff in the Ouachita Mountain region (abstract): Creol. 'Soc. A merica Bull., vol. 31, pp. 125-126, 1920. Honess, C. W., The Stanley shale of Oklnhoma: Am. Jour. Sci., 5th ser., vol. 1, pp. 63-80, 1921; also op. cit.

s1 Personal communication. saw County, Miss., and near Maben in Webster and Oktibbeha Counties, Miss.; and in the Clayton formation or the Porters Creek clay in western Union County, across Pontotoc County, and along the Gulf, Mobile \& Northern Railroad in Tippah County, Miss.

An unusually pure bentonite occurring near Aberdeen, Monroe County, Miss., is reported by the State geologist ${ }^{52}$ to be part of the Eutaw formation.

A bed of glassy volcanic ash probably of Jackson (late Eocene) age occurs in the northeast part of La Salle Parish, La. ${ }^{53}$ The ash bed is 4 feet thick at the outcrop and is reported to be 35 feet thick in a drill hole near by. This material is nearly pure white and very fine grained and contains from 10 to 15 per cent of crystalline quartz, feldspar, etc.

Tuff of Oligocene or lower Miocene age is widely distributed in Live Oak and McMullen Counties, 65 to 90 miles south of San Antonio, Tex. ${ }^{54}$

Volcanic ash of several different ages in Arkansas and Louisiana is briefly described by Crider, ${ }^{55}$ who says: "Volcanic ash has been discovered in a number of *** localities in Louisiana and Arkansas ranging in age from Lower Cretaceous to the Jackson formation of the Eocene."

Volcanic ash is mentioned by Dumble ${ }^{56}$ as occurring in Texas in the Fayette, Yegua, and Jackson formations (Eocene), in beds of upper Oligocene age, and in the Oakville sandstone (Miocene).

Volcanic ash from the Hayes district of Calcasieu Parish, La., has been described recently by Hanna, ${ }^{57}$ though the age of the ash is not known to him. The core he examined came from a depth of 1,510 feet in the Duhig et al. No. 1 Levey well.

\section{DISTRIBUTION OF THE TUFF TYPES}

The general distribution of the tuff beds has been stated, but for the purpose of petrographic description it is convenient to take them up in five rather distinct groups of occurrences. One of these comprises the region north and northwest of Nashville, Ark., where the orthoclase trachyte pumice tuffs are the thickest and composed most largely of igneous material. Another is the area of Arkansas where the phonolite tuffs occur. Over part of the area the beds of the first group overlie those of the second, but from Blue Bayou west to the State line the pumice tuffs are not well developed so far as known. A third group of occurrences is in Oklahoma, and a fourth includes the

${ }^{32}$ Lowe, E. N., personal communication.

83 Personal communication from W. M. Weigel, mineral technologist of the Missouri Pacific Railroad.

54 Bailey, T. L., Extensive volcanic activity in the middle Tertiary of the south Texas Coastal Plain: Science, new ser., vol. 59, pp. 299-300, 1924.

ss Crider, A. F., Volcanic ash in northern Louisiana: Am. Assoc. Petroleum Geologists Bull., vol. 8, pp. 524-525, 1924.

${ }^{86}$ Dumble, E. T., A revision of the Texas Tertiary section with special reference to the oil-well geology of the coast region: Am. Assoc. Petroleum Geologists Bull., vol. 8, pp. 424-444, 1924 .

87 Hanna, M. A., An interesting volcanic ash from Calcasicu Parish, La.: Am. Assoc. Petroleum Geologists Bull., vol. 10, pp. 93-95, 1926. 
tuff-bearing beds of Texas. 'The fifth comprises the occurrences in the Prothro dome and the Rayburn salt dome.

The minerals and their relative proportions differ greatly from place to place, and no single specimen is entirely characteristic of a locality, but tuffs from a locality in each of the above five groups were unsually fresh and have been studied in detail. The material was prepared for study by washing, and the heavy minerals were concentrated by heavy solutions. The results of this study are given in the table below. Where mineral or rock grains were present in essential amounts the approximate proportions were determined and are given in figures. If a mineral formed less than 1 per cent of the material, its presence but not its proportion was determined and is indicated by an $\times$. The purer specimens of all the tuffs were selected for: study, and the figures given do not imply that all the specimens from a given locality had the high content of volcanic materials indicated.

Rocks and minerals of the tuffs

\begin{tabular}{|c|c|c|c|c|c|}
\hline \multirow[t]{2}{*}{ v } & \multirow{2}{*}{$\begin{array}{c}\begin{array}{c}\text { Ortho- } \\
\text { clase } \\
\text { trachyte } \\
\text { tuffs }\end{array} \\
1\end{array}$} & \multicolumn{4}{|c|}{ Phonolite tuffs } \\
\hline & & 2 & 3 & 4 & 5 \\
\hline 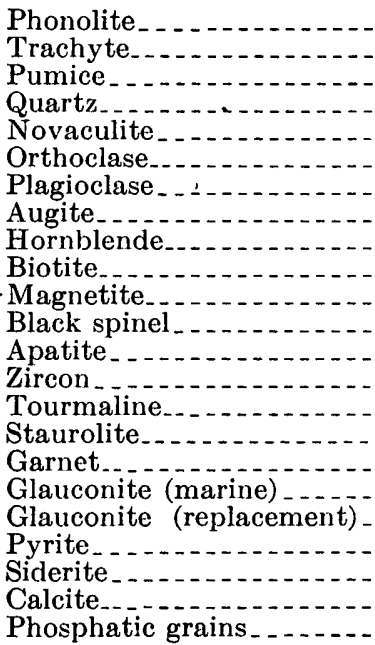 & 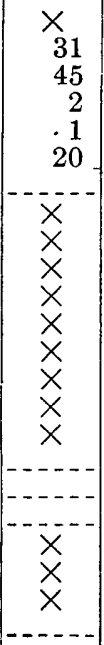 & 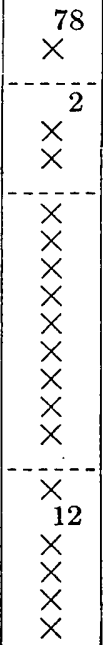 & 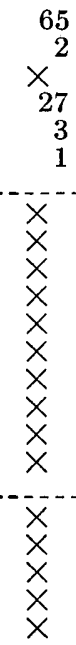 & 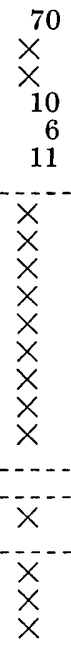 & 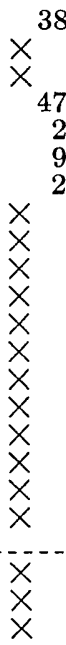 \\
\hline
\end{tabular}

1. From Blue Bayou, Ark., representing orthoclase trachyte tuffs.

2. From Owen Place, Ark., unusually pure phonolite tuff. (See fig. 17.)

3. From Garvin, Okla. (See pl. 20.)

4. From Arthur City, Tex. (See pl. 20.)

5. From the Prothro salt dome, La.

The last four columns of the table show a great variation in the proportions of volcanic and detrital sedimentary rock débris, but the igneous-rock minerals show practical identity, even though the localities from which they came were widely separated. The metamorphic-rock minerals and the minerals that developed subsequent to deposition are also identical. The orthoclase is all sanadine, the augite crystals all show the cockscomb habit, and the hornblende is similar in color and habit. Black spinel, which is a very unusual mineral in volcanic rocks, is present in every sample studied. The glauconite that formed films around rock and mineral grains was later than deposition in all the specimens.

\section{THE TUFF BEDS OF ARKANSAS}

MINE CREEK, HOWARD COUNTY, ARK.

The tuffs, tuffaceous sands, and associatcd gravel and boulder beds crop out for about 1 mile along Mine Creek, 3 miles north of Nashville, Ark. (See fig. 17.) The beds change greatly in character within short distances, and there is locally a very large admixture of nonvolcanic detrital rock. For this reason the tuff beds on Mine Creek are hard to describe systematically, but the chief types of material will be mentioned.

The tuff beds contain many beds and lenses of gravel and boulders, and the rock materials are predominantly quartz and novaculite, but locally there are many pebbles and cobbles of igneous rock of the same type that forms the small rounded rock pellets of the lithic phonolite tuffs. The most abundant igneous material on Mine Creek is composed of rounded grains of phonolite mixed with quartz and novaculite grains and with various proportions of pumice and trachyte fragments.

The bentonitic beds derived from glassy pumice usually contain large proportions of other rock materials, but one mass of unusual purity crops out at water level on the west side of the creek. It is cream-white and is composed of clay grains derived from pumice, a very little finely crystalline trachyte, and about 25 per cent euhedral orthoclase. The clay grains retain perfectly the fibrous pumice structure. The clay portion is of unusual purity and was separated and analyzed. (See p. 186.) At the base of the pumice mass is a layer of small phonolite pebbles that are almost completely kaolinized.

At nearly the same horizon are beds of deep-red sandy clay that are composed of orthoclase, pumice fragments altered to clay, and altered trachyte fragments. The red layer is in sharp bedded contact above and below with beds of normal color, and it is evident that oxidation occurred during or before deposition and is not the result of recent weathering.

Pebbles of red clay were noted by C. H. Dane ${ }^{58}$ in the tuff three-quarters of a mile south of.Lockesburg. They were apparently derived from a bed of red clay older than the tuff, and they were oxidized before they were deposited in their present position, which is about 20 feet above the base of the Woodbine. 
COLEMAN CREEK, HOWARD COUNTY, ARK.

The tuff layer crops out for about three-quarters of a mile along the banks and in the bed of Coleman Creek, locally called Temperanceville Creek, about 3 miles northwest of Nashville. (See fig. 17.) The total thickness of the exposed beds is about 12 to 15 feet, and two small prospect pits have penetrated the tuffs some feet below water level. The beds are all claylike, for they are all derived from pumice tuff, and they contain accessory grains and fragments of lithic trachyte. Phonolite tuff beds are not exposed on Coleman Creek. The pumice contains abundant orthoclase, but other phenocrysts make less than 2 per cent of the rock.

The minerals identified after concentration by heavy solutions are biotite, titanite, magnetite, and black spinel. Augite is present but it was possibly derived from phonolite fragments and not from the pumice tuffs. A little tourmaline and garnet are occasionally seen among the heavy minerals.

The predominant material is the gray bentonitic clay derived from angular altered grains of glassy pumice. These béds contain many calcite concretions that form masses with a maximum diameter of several feet that are especially abundant in the creek bed. It was one of these masses of calcite-cemented tuff from Coleman Creek, submitted to the Geological Survey by Mr. J. N. Garner, that led to the recognition of volcanic material in the region.

The rock fragments in the pumice tuffs are angular or subrounded, not well rounded like the phonolite rock fragments. The trachyte fragments have resisted weathering better than the phonolite and are fresh for the most part, and these heavy minerals are identical with those found in the pumice tuffs. The analysis of the orthoclase trachyte given on page 186 was made on fresh grains that were picked by hand from the tuffs on Coleman Creek. These ranged from 1 to 10 millimeters in diameter and were nearly white. They were composed of euhedral orthoclase in a very fine grained aphanitic groundmass of alkalic feldspar without characteristic crystal form. The rock was almost without dark minerals, but an occasional grain of biotite, titanite, magnetite, or black spinel could be observed.

PLEASANT VALLEY CREEK, HOWARD COUNTY, ARK.

Pleasant Valley Creek drains eastward into Mine Creek, and along its bed the tuffs are well exposed. (See fig. 17.) Here there is a smaller admixture of nonvolcanic rock débris than on Mine Creek, and claylike material, derived from glassy volcanic tuffs, and angular lithic fragments are the most conspicuous materials of the beds. Small fragments of trachyte are especially abundant in the creek bed but do not differ from those on Coleman Creek.
BLUE BAYOU, HOWARD COUNTY, ARK.

Some of the most extensive exposures of volcanic tuff in the entire region are found on Blue Bayou, extending from a point a short distance west of Forgy almost to Center Point. The best of these are near Blue Bayou Church, where about 40 feet of the tuff is exposed. (See fig. 17.)

All types of volcanic débris are represented, but the gray and blue-gray claylike material is probably the predominant component. With this are mixed trachyte pumice fragments and angular orthoclase trachyte fragments, rounded rock pellets of the phonolite tuff, and various proportions of nonvolcanic rock material. The beds are lens-shaped and show very marked cross-bedding, and the size and character of the material at a particular horizon change laterally within a few rods.

The most abundant form of tuff at Blue Bayou Church is a loosely coherent material of light bluishgray color. It is made up of claylike pellets that have been derived from glassy pumice fragments, trachyte grains, igneous-rock phenocrysts, and a small amount of quartz and other detrital material derived from sedimentary rocks. The grains range in diameter from about 1 millimeter to 15 millimeters.

The minerals are largely orthoclase, but biotite, titanite, and black spinel form less than 2 per cent of the rock. The orthoclase is very perfectly euhedral for the most part, but a few crystals are etched, and many are fractured so that only one end of the crystal is complete. Biotite is the most abundant dark mineral and occurs in flakes with euhedral outline. The black spinel has euhedral form and very brilliant crystal faces. Pale-brown shotlike pellets of siderite with radial structure and a little pyrite are secondary minerals that developed subsequent to the deposition of the ash.

Another specimen from Blue Bayou Bluff represents material that is composed of lithic and vitric tuffs in about equal parts. It is light bluish gray and is composed of fragments that reach a maximum length of about 5 millimeters. These are angular fragments of finely crystalline trachyte, flattened fragments of pumice, and mineral grains that represent igneousrock phenocrysts.

A microscopic study of thin sections shows that the pumice has been altered to a bentonitic clay mineral, many grains of which have a lens shape, which is due to flattening by compression and loss of the original pumiceous porosity. The microscope shows that many of these clay grains are made up of a micaceous mineral with high birefringence. Each pumice fragment appears to be a single distorted individual crystal of clay material. It is evident that during alteration the porous individual grains became flattened and accommodated themselves to the contour of the contiguous grains and thus assumed a distorted shape. 
Of the mineral grains that represent phenocrysts from the igneous rock, orthoclase is the only one that is abundant. Rare dark minerals are augite, biotite, titanite, green and brown hornblende, apatite, magnetite, black spinel, and pink garnet. The rock differs from the phonolitic tuff on the Owen place, described below, in having abundant biotite but little augite.

OWEN PLACE, HOWARD COUNTY, ARK.

The basal part of the tuff beds, where the phonolite tuffs are exposed in unusual perfection, crops out along the northern border of the tuff area at many points between Center Point and Corinth,HowardCounty,Ark. One of the best sections is found on the Owen place, about 3 miles west of Corinth, in the valley of a small northward-flowing stream. (See fig. 17.)

Boulders, some of which reach a maximum diameter of several feet, are scattered over the surface and locally they are very abundant. These are indurated masses of pumiceous tuff that were originally cemented with calcium carbonate. The carbonate has since been partly or wholly leached away in the boulders that have long been lying on the surface, but others that have not been subjected to prolonged weathering still contain much calcium carbonate.

The delicate structure of very porous, almost feather-like pumice fragments is to be seen in many of the boulders where the pumice has been exposed by the leaching away of the inclosing calcium carbonate. In other boulders the pumice glass itself has been partly or wholly replaced by calcium carbonate, and in these the pumice structure has been completely preserved and is recognizable under the microscope even where the rock is all calcium carbonate. (See pl. 22, B.)

The calcium carbonate boulders occur embedded in the bentonitic clay beds derived from tuffs, and as the structure is the same in both types of material, it seems evident that both are derived from the same glassy pumice beds. The local cementation of the glassy pumice into the boulderlike masses must have taken place before the tuffs were altered, for the delicate tuff structure and the thin-walled vesicular cavities are perfectly preserved. The greater part of these beds remained uncemented, and underwent the normal devitrification process by which glassy volcanic tuff was altered to a bentonitic clay mineral.

Outcrops of clay beds derived from pumice tuff are not numerous in the area, but these beds do not form good outcrops, and it is probable that deposits of pumice tuff are more numerous and thicker than the exposures would indicate.

The phonolite tuffs on the Owen place, 3 miles west of Corinth, are among the best examples of this type of material in the entire region. Large masses have been completely indurated by the infiltration of calcium and iron carbonates. The color of phonolite tuff is gray-green or dark olive-green. The material is rather well sorted, as only a small portion of the grains range between 0.2 and 0.4 millimeter in diameter and most of them are between 0.5 and 1 millimeter. All the grains are surrounded by a film of gray-green glauconitic material about 0.01 millimeter in thickness, and the igneous rock and minerals have been partly replaced by it. Well-rounded fragments of phonolite rock form one-third to two-thirds of the pellet-like grains that make up the rock and are the most abundant single material present. The finegrained groundmass feldspar of the phonolite appears to be fresh, although there has probably been some kaolinization, and the associated ferromagnesian minerals are fresh. All rock grains retain the texture of a trachytic phonolite, and some are so fresh that nephelite can be recognized. Novaculite grains are present but are not abundant, quartz in well-rounded grains is the next most abundant material present, and red grains of iron oxide form several per cent of the rock.

Volcanic-rock minerals that represent phenocrysts make up about 5 per cent of the grains. These in the order of their abundance are orthoclase, pale-green augite, dark-green hornblende, titanite, magnetite, black spinel, biotite, red-brown basaltic hornblende, apatite, and zircon. Most of these crystals are perfectly euhedral. A few show a very little rounding, but the greater part have sharp, brilliant crystal faces. This is especially true of spinel, magnetite, hornblende, titanite, and orthoclase. The pale-green augite has the cockscomb-like multiple terminations shown in Plate 24, $A$.

Carbonate completely fills the spaces between the grains in the indurated boulderlike masses. The presence of these nodular masses and the manner in which some of the mineral grains have been replaced indicate that the calcium carbonate was brought in by solution. This inference is confirmed by the presence of the glauconitic films around the grains that must have been formed in place and prior to the deposition of the calcium carbonate.

\section{THE TUFFACEOUS SANDS IN TEXAS}

The tuffaceous sands of the Woodbine formation in northeastern Texas occur mainly in a well-defined zone 200 or 250 feet below the top of the formation as it is defined in Red River and Lamar Counties. The sands of this zone have been examined at seven localities, six of which are alined in a nearly direct east-west line in the northern part of Red River and Lamar Counties and the seventh is in the northwestern part of Fannin County. (See pl. 20.) A small percentage of volcanic material has been found also in sands of questionable Eagle Ford or basal Austin age near Woodland, in Red River County, and near Medill, in Lamar County, but these sands can hardly be called tuffaceous, and their small content of volcanic material may have here been derived by reworking 
from older tuffaceous beds. The rocks at this locality, though they resemble the Woodbine formation contain the species Ostrea sannionis White, which by comparison with the occurrence of the type of this species in the Western Interior, suggests either the Benton or the lower Niobrara and therefore either the Eagle Ford or the lower Austin age of the beds. As high as 20 per cent of volcanic material was found in a grecnish-gray sandstone lying only 10 feet below the top of the Woodbine formation and having an exposed thickness of 3 or 4 feet, in a low bluff on Red River, $11 / 2$ miles north of the Ragtown settlement in the northwestern part of Lamar County.

The mineral composition of material from the locality is as follows:

Composition of sandstone containing volcanic material $11 / 2$ miles
north of Ragtown, Tex.

Quartz
Orthoclase
Magnolite
Titanite, biotite, zircon, tourmaline, stauro-
$\quad$ lite, and black spinel

The tuffaceous sands of Texas are similar to the phonolite tufts from the Owen place and Blue Bayou in Arkansas. (See fig. 17.) Most of them contain a larger proportion of detrital quartz and a little novaculite, but a few specimens are predominantly volcanic material. The igneous material at Arthur City is largely in the form of rounded fragments of finegrained phonolite, but a few grains of the trachyte are present, and a very few grains of altered glassy pumice are to be found. The mineral grains observed are orthoclase, a very little sodic plagioclase, biotite, augite, hornblende, titanite, magnetite, black spinel, and apatite. Magnetite, spinel, and titanite appear to be nearly as abundant as in the Arkansas localities, but hornblende and augite are extremely rare in most of the Texas deposits. A study of thin sections indicates that augite was originally abundant but has been almost completely replaced by calcium carbonate. The orthoclase, titanite, biotite, spinel, and magnetite show subhedral to euhedral forms but are less commonly cuhedral than in Arkansas. A few grains of brown tourmaline are present in all the samples. Orthoclase biotite, titanite, and black spinel are minerals that are more abundant in the pumice and trachytic tuffs than in the phonolite tuffs in the Arkansas areas, and this seems to indicate that trachyte and phonolite have both contributed material to the Texas beds, although fow trachyte grains and less glass are now recognizable in them. It seems probable that the greater distance of the Texas beds from the volcanic source has resulted in the destruction of the more delicate structures during transportation, and that in this way the pumice has largcly disappeared, but at the same time the orthoclase and other minerals that represent the phenocrysts from the same source have escaped destruction.

\section{SILVER CITY FERRY, RED RIVER COUNTY}

Silver City Ferry, on Red River, is in Red River County, Tex., about 17.5 miles almost due north of Clarksville, the county seat. The bluff below the ferry reveals about 15 feet of tuffaceous sandstone of the Woodbine sand, overlain by about 10 feet of river alluvium consisting of loam, clay, and sand, with a band of gravel along the base. (See pl. 25, A.)

The tuffaceous sandstone is a coarse green pebbly cross-bedded sand, irregularly cemented with calcite, which gives to the rock a silvery sheen. Thin veins of calcite also cut the sandstone in places. The sandstone dips perceptibly downstream and is underlain between the main exposure and the ferry by 10 feet of dark clay containing some vegetable particles and near the top a few poorly preserved leaves. Near the middle of the clay is a band of soft cross-bedded sandstone containing a few poorly preserved pelecypod casts and molds and some nodules of marcasite.

About 100 yards above the ferry and apparently at a lower stratigraphic level than the dark clay the bluff exposes 6 or 8 feet of greenish-gray clay with partly indurated sandy lenses near the base, and below this clay is 4 or 5 feet of mottled purplish sandy clay exposed just above water level.

All the materials exposed in the vicinity of the ferry, except the overlying river alluvium, belong to the Woodbine sand.

The specimens collected at Silver City Ferry are a dark gray-green calcite-cemented tuffaceous sand, in which volcanic-rock materials are more abundant than detrital grains. The following rock materials and minerals have been identified: Phonolite, quartz, novaculite, orthoclase, hornblende, magnetite, black spinel, titanite, zircon, apatite, garnet, and tourmaline.

\section{EAST OF KANAWHA, RED RIVER COUNTY}

Five or six feet of tuffaceous sand of the Woodbine formation is exposed in a ravine 2 miles east of $\mathrm{Ka}$ nawha, about 0.2 mile southeast of the intersection of the Manchester-Klomatia and Kanawha-Scrap roads. (See pl. 20.) The locality, which is about 20 miles northwest of Clarksville, is especially interesting on account of the occurrence of many individuals of Ostrea soleniscus Meek, a characteristic Woodbine species, in the tuffaceous sand.

The sand is irregularly bedded and consists of quartz, fragments of volcanic rock and minerals, glauconite, and novaculite, named in the approximate order of their abundance. Some clay is interbedded with the sand. The sand is irregularly indurated to nodular masses. The oysters occur in great numbers, mainly in 
the lower 3 feet of the section, where in places the shells are attached to one another in clusters. The shells are not well preserved and are difficult to collect in good condition. This locality was reported to Stephenson by W. B. Sprague, a geologist of the Gulf Production Co., who visited it in 1924.

The calcite-cemented tuffaceous sands examined from the Kanawha locality contained not more than 25 per cent of volcanic materials among the mineral grajns. The specimens are characterized by numerous fossil fragments, by a large proportion of cementing calcite between the mineral grains, and by abundant glauconite. Augite was originally present but has been completely altered to a calcite-glauconite aggregate. The following table gives the approximate mineral composition:

Minerals and rock grains of tuffaceous sand east of Kanawha

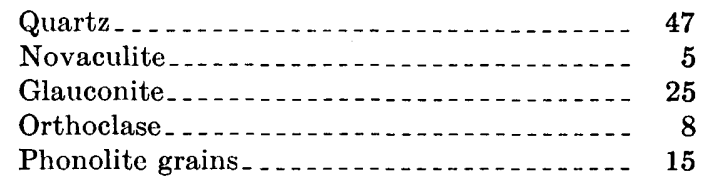

Minerals present in small quantities are biotite, hornblende, magnetite, black spinel, titanite, garnet, apatite, phosphatic grains, siderite, and pumice.

PINE BLUFF FERRY, RED RIVER COUNTY

The tuffaceous sand of the Woodbine is well exposed at Pine Bluff Ferry, Red River County, about 23 miles northwest of Clarksville, Tex. (See pl. 20.) The river touches the edge of a high terrace plain at this locality, revealing the following section:

Section at Pine Bluff Ferry, on Red River, Red'River County, Tex.

Pleistocene terrace deposit: Alluvial loam, sand, and Feet

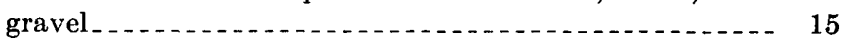

Upper Cretaceous (Woodbine sand):

Massive sticky clay, poorly exposed.

Coarse water-laid tuffaceous sand with only a small percentage of quartz and novaculite; the sand is partly indurated, exhibiting many oval to irregular concretionary masses.........................

Stratified tuffaceous sand with subordinate layers of quartz sand and some thin interbedded clay layers; contains some comminuted plant fragments....... 33

Concealed by flood water; reported........ 6

The specimens collected at Pine Bluff are a dark gray-green calcite-cemented tuffaceous sand, in which volcanic materials are unusually abundant and fresh. The rocks and minerals present are listed below:

Mineral and rock grains of tuffaceous sand at Pine Bluff Ferry, Tex.

Phonolite......... 70

Orthoclase .............. 10

Quartz . . . . . 5

Novaculite.... 3

Augite
Small quantities of hornblende, magnetite, black spinel, titanite, garnet, apatite, and zircon are present.

\section{GOLDEN BLUFF, RED RIVER, LAMAR COUNTY}

Golden Bluff on Red River, 3 miles east of Arthur City, Lamar County, Tex. (see pl. 20), exhibits another section in the edge of a high Pleistocene terrace, the lower 35 feet of which is composed of tuffaceous sand.

Section at Golden Bluff on Red River, Lamar County, Tex.

Pleistocene terrace deposit: Alluvial sand, poorly ex- Feet posed................................... 35

Upper Cretaceous (Woódbine sand):

Gray, more or less sandy, crumbly clay, with comminuted plant fragments . . . . . . . . . . . . . . .

Soft to hard, fine-grained, finely glauconitic sandstone, with fossils abundant in places......... $0.5-1$

Interbedded sandy shaly clay and impure fine sand, weathering somewhat mealy; a few imperfect fossil leaves noted................................

Coarse, irregularly bedded mealy tuffaceous sand, indurated in part to irregular, more or less nodular masses. The sand is mainly quartz but contains a considerable percentage of volcanic material, a few pebbles, and a few fragments of fossil wood. Only 15 feet is exposed at the lower end of the bluff, but the sand rises upstream, reaching an exposed thickness at the upper end of the bluff of

The molluscan species found in the glauconitic sandstone are for the most part poorly preserved and with one questionable exception have been only generically identified. The bivalves include Nucula, Ostrea soleniscus Meek?, Exogyra, Pecten, Plicatula, Pholadomya, Isocardia?, Aphrodina, and Cyprimeria; the univalves are represented by Gyrodes?, Apporhais and several unidentified forms; and there are two chambered shells belonging to the ammonite genera Metoicoceras, and Metengonoceras. Although in the light of present knowledge of the ranges of these fossils none of them' afford conclusive evidence of the age of the containing bed, comparison with other collections suggests that the bed belongs to the upper part of the Woodbine formation.

The tuffaceous sands at Golden Bluff are predominantly quartz but contain about 25 per cent of volcanic materials. Phonolite rock fragments form about 20 per cent, and small amounts of orthoclase, plagioclase, biotite, chlorite, apatite, and calcite-glauconite areas that represent altered augite are present.

\section{ARTHURS BLUFF, LAMAR COUNTY}

Arthurs Bluff, on the south bank of Red River just north of Arthur City, Lamar County, Tex., is one of the most accessible localities for studying volcanic material in the Woodbine sand, being reached both by rail and by highway. (See pls. 20, 25, B, and 26.) The bluff serves as the south abutment of the Frisco Lines railroad bridge across Red River and as the south 
abutment of the bridge on the highway between Paris, Tex., and Hugo, Okla.

Exposures of cross-bedded tuffaceous sand occur below the highway bridge and at and below the lower ferry and extend up the face of the bluff to a level about 10 feet above the river. (See pl. 25, B.) The sand is interbedded with and overlain by dark laminated more or less sandy clay, which rises at least 20 feet above the river and which contains many wellpreserved fossil plants. A collection of plants, obtained chiefly in clay above the main band of tuffaceous sandstone at this locality, was described by Berry, ${ }^{59}$ but fossil leaves were noted in the tuffaceous beds also. The sand is in large measure cemented by calcium carbonate, and the parts so cemented crop out as ledges and as nodular and irregular masses a foot or more in diameter. The sand is coarse to fine grained and is olivegreen when fresh but changes to yellowish green on weathering. Thin layers of clay ironstone (iron carbonate) are common in the sand, but at the lower ferry there is a lens of this carbonate ranging in thickness from a feather edge to 15 inches. Just below the highway bridge a projecting ledge of tuffaceous sandstone, in places 5 feet thick, contains pebbles of novaculite and other rocks and in its lower part laminated masses of clay ironstone as much as 3 feet in diameter that have been tilted into all positions from horizontal to vertical. The sandstone of the projecting ledge is thus a conglomerate.

At the upper ferry, above the railroad bridge, a section is exposed which consists chiefly of irregularly bedded dark-gray to greenish-gray sandy shaly clay of the Woodbine formation rising 20 to 25 feet above the river. At the upper end of the bluff several lenses of tuffaceous sand were noted in the clay. Leaf impressions occur in the clay in piaces.

The Woodbine at Arthurs Bluff is overlain by 2 to 15 feet of Pleistocene alluvial terrace deposits.

The volcanic tuffs are very well represented at the Arthur City Ferry, and their unusual purity at some horizons and the perfect preservation of materials make this the best locality in Texas for their study. The color ranges from yellowish green to dark graygreen where perfectly fresh. The color is due to glauconitic films around the individual mineral and rock grains. Secondary calcite has cemented the grains into rounded concretions, and commonly the concretions, several inches in diameter in large areas, have uniform orientation and give an ophitic appearance to the rock. The rock and mineral grains average about 0.5 millimeter in diameter.

A representative specimen of the rock is made up of mineral and rock grains in the following proportions, and these are inclosed in calcite:

${ }^{80}$ B Berry, E. W., The flora of the Woodbine sand at Arthurs Bluff, Tex.: U. S. Geol. Survey Prof. Paper 129, pp. 153-181, 1922.
Mineral and rock grains of tuff beds at Arthur City Ferry

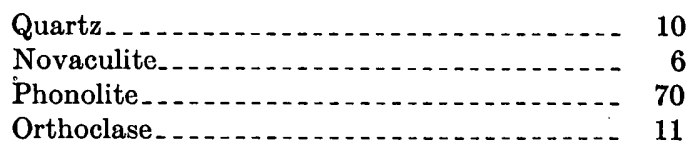

With these are minor quantities of trachytic rock grains, pumice, augite, hornblende, biotite, magnetite, black spinel, apatite, zircon, tourmaline, staurolite, siderite, and phosphatic grains.

In all the specimens phonolite is the dominant igneous rock material, but trachytic volcanic rock fragments, orthoclase, and small quantities of dark minerals are always present. The phonolite grains have been largely altered to a green "chloritic" material that chemical tests seem to indicate are glauconite.

\section{GARRETS BLUFF, RED RIVER, LAMAR COUNTY}

The next locality west of Arthurs Bluff at which the main bed of tuffaceous sand of the Woodbine has been examined is at Garrets Bluff on Red River, about 18 miles northwest of Paris, Lamar County, Tex. (See pl.20.) The section is in the edge of a Pleistocene terrace that lies about 25 feet above low-water level, and the upper 15 feet of the section is composed of river alluvium.

The tuffaceous sand is exposed beneath the alluvium for about 100 yards along the face of the upstream end of the bluff. The sand is coarse, greenish, and cross-bedded and is made up of quartz sand and volcanic materials in differing proportions in different parts of the bluff. One sample was obtained that was composed largely of volcanic materials. The sand is unevenly indurated, in places exhibiting round concretionary masses. One relatively small lens of hard, dense shattered iron carbonate was observed. A few pieces of silicified wood were noted in the sand. The tuffaceous sand dips perceptibly upstream and is underlain first by several feet of dark laminated clay and below this by massive purplish-mottled clay, which chiefly makes up the bluff below the alluvial covering for the remainder of the distance downstream to the lower end of the bluff which has an estimated length of about half a mile. The section is very similar in its lithologic characters and in the succession of beds exposed to the bluff at Silver City Ferry, in Red River County. The tuffaceous sand at Garrets Bluff has a characteristic mineral and rock composition similar to that at Arthur City Ferry.

\section{HYATTS BLUFF, FANNIN COUNTY}

Hyatts Bluff, on the south bank of Red River, 7 miles. northwest of Ravenna, Fannin County, Tex., reveals the westernmost observed exposure of tuffaceous sand in the Woodbine formation. (See pls. 20 and 27.) 
The exposure, about half a mile long and 25 feet high, is in a steep slope and cliff that rise from the water's edge. The upper half of the exposure shows dark laminated clay interbedded with thin layers of greenish tuffaceous sand. Both the clay and the sand contain many nodules and lenses of dark-gray clay ironstone (iron carbonate), some of them 2 inches thick, and in one layer of clay marine invertebrate fossils were found. The lower half of the exposure consists of greenish fine to coarse-grained cross-bedded sandstone in which there are a few invertebrate fossils and some clay ironstone both as pebbles and nodules. Some of the sandstone on weathering takes the form of spherical masses, the largest a few feet in diameter. The rocks in the exposure at this locality were described by Stephenson ${ }^{60}$ in 1918, but the tuffaceous character of some of the beds was not then recognized.

The tuffaceous sands from Hyatts Bluff are predominantly volcanic material, but with this is an unusually large proportion of siderite in rounded grains with a radial habit. There are many rock grains made up of quartz and feldspar in a greenish clay matrix, and these evidently represent fragments of an older sedimentary rock that have been transported to their present location without disintegration. The presence of volcanic material in the grains indicates that redeposition has taken place since the first volcanic activity. The phonolite fragments are unusually well preserved, but associated with these are trachyte and pumice fragments. Therefore both phonolite and trachyte have contributed material to form the beds at Hyatts Bluff.

\section{PHONOLITE TUFFS OF LOUISIANA}

Volcanic tuffs of the phonolite type crop out on the Prothro salt dome, in T. 14 N., R. 6 W., Bienville Parish, La. ${ }^{61}$ where they form beds 75 feet thick that stand almost vertical. Volcanic material of the same kind has been found in the Rayburn salt dome, in T. 15 N., R. 5 W., Bienville Parish. It has also been found at a depth of 2,945 feet in sec. $28, T .14$ N., R. 6 W., Bienville Parish, about 3 miles south of the Prothro salt dome, and at a depth of 2,456 feet in a well in sec. 16, T. 22 N., R. 3 W., Claibourne Parish. Specimens from the Prothro dome were collected by Spooner, and the minerals and lithology were studied by Ross and the fossils by Stephenson. The fossils indicate, according to Stephenson, that this rock is younger than the Eagle Ford clay and is probably of the age of the typical Austin chalk and of the Tokio formation.

The tuffaceous sand that crops out in the Prothro dome, although younger than the phonolitic tuff beds

\footnotetext{
60 Stephenson, L. W., A contribution to the geology of northeastern Texas and southern Ozlahoma: U. S. Geol. Survey Prof. Paper 120, pp. 145-146, pl. $25 A, 1918$. ${ }^{61}$ Spooner, W. C., Am. Assoc. Petroleum Geologists Bull., vol. 10, pp. 245-256, 1926.
}

in Arkansas, Oklahoma, and Texas, differs from them in no essential characteristic. The approximate proportions of its rock and mineral components are listed on page 194. Small, well-round edgranules of phonolite low in dark minerals are, next to quartz, the most abundant material in the rock. Orthoclase is present in considerable proportions, and augite, plagioclase, hornblende, titanite, biotite, magnetite, black spinel, apatite, and zircon are igneous-rock minerals that occur in small proportions. Minerals that have developed since deposition are glauconite, siderite, calcite, and pyrite. Metamorphic-rock minerals are garnet, tourmaline, and staurolite. The beds are completely cemented with calcite like some of those in the Texas areas. Two types of glauconite are present; one, consisting of small rounded blue-green granules composed of overlapping crystal plates, is the normal glauconite that is believed to form on the sea bottom during sedimentation, and the other is the yellow-green material that formed after sedimentation ceased and replaced mineral grains and rock fragments. The beds at the Prothro dome differ slightly from the tuffs of Arkansas in containing marine fossils, a larger proportion of the marine type of glauconite, and a little plagioclase. Volcanic material of the same type occurs in the Rayburn salt dome, about 5 miles northeast of the Prothro dome. ${ }^{62}$

\section{RILEY PLACE AND TWIN KNOBS, PIKE COUNTY, ARK.}

The best exposures of the peridotite tuff (?) are on the Riley place, in the W. $1 / 2 \mathrm{SW} .1 / 4$ sec. $22, \mathrm{~T} .8 \mathrm{~S}$., R. $25 \mathrm{~W}$., half a mile northeast of the Ozark diamond mine near Murfreesboro, Pike County, Ark. (See pl. 20.) The material, which was studied by Miser in 1912, was revealed at the time of examination in a well, a pit, and two trenches. Marion Riley, who dug the well, says it was originally $411 / 2$ feet deep and that the tuff (?) extends to the bottom and the well did not go through it. The well at the time of examination was only 18 feet deep. The pit south of the Riley house is 12 feet deep. The bed here consists of a greenish-yellow coarse-grained earth and shows lamination and cross-bedding. It consists principally of well-rounded grains of quartz sand intimately mixed with possibly an equal or larger quantity of altered serpentine grains and a little mica in small flakes. Some quartz pebbles and fragments of gray sandstone, semivitrified clay, black shale, and weathered peridotite are also present. A horizontal layer of clay and several lenses of clay lying along bedding planes were observed. Some diamond prospectors have thought that the tuff (?) bed is weathered peridotite and that it forms a part of an eastward extension of the peridotite body that is exposed half a mile to the southwest, near the mouth of Prairie Creek. The mineral com.

62 Spooner, W. C., op. cit., pp. 260-265. 
position of the bed and the arrangement of its material, however, show without doubt that the bed was waterlaid. The bed apparently lies at the base of the Tokio formation (Upper Cretaceous) in this locality.

Another exposure of the peridotite tuff (?) was observed in 1912 by Miser in two small pits on the north side of Twin Knobs, near the center of sec. 22, T. 8 S., R. 25 W., a mile east-northeast of the Ozark diamond mine. The following section was measured on the north slope from the base to the top of the north knob.

\section{Section of Tokio formation at Twin Knobs}

Gravel on top of hill and on slope; in places there are exposures of clay . .

Gravel . . . . . . .

Clay; the earth shown in the two pits is near the middle of this bed; altered serpentine grains and mica are present in the material. .......................... Gravel (base of Tokio formation) ..................... Clay (Trinity formation) . . . . . .

DIAMONDS IN VOLCANIC DEPOSITS OF WOODBINE AND TOKIO FORMATIONS

Diamonds have been prospected for in the peridotite tuff of the Tokio formation on the Riley place, half a mile northeast of the Ozark diamond mine, near Murfreesboro, Ark. Search has also been made for them in volcanic tuff in the Woodbine formation on and near Mine Creek, from 3 to 4 miles north of Nashville, Ark. (See fig. 17.) No diamonds have thus far been reported from the Riley place, but the discovery of five small stones has been reported from the Will Sanger place, 4 miles north of Nashville, and three small stones have been reported from the George Power place, 3 miles north of Nashville. (See fig. 17.)

Some stones may occur in the peridotite tuff (?) on the Riley place and at other localities of such tuff, but it does not secm likely that the diamond content would equal that of the diamond-bearing peridotite at the mines near Murfreesboro, Ark. This conclusion apparently follows from the fact that much sand and sedimentary clay are component parts of the tuff.

The discovery of additional stones may be reported from the volcanic tuff of the Woodbine near Nashville, but the fact that only a very small quantity of peridotite fragments-if any actually are present-occurs in the tuff leads to the conclusion that not more than a few stones will ever be found in the tuff.

The peridotite tuff (?) on the Riley place, contains pebbles of peridotite and grains of altered serpentine that were washed from an exposure of peridotite or were ejected as fragmental material from volcanic vents. This material apparently lies at the base of the Tolkio formation in this locality. To determine whether or not the material contains diamonds the Ozark Mines Corporation washed 1,000 loads (16 cubic feet each) of it. No diamonds were found.
The prospecting for diamonds on Mine Creek 4 miles north of Nashville has been done at times by various persons. The work, which has been done on land belonging to Will Sanger, consisted of digging volcanic tuff from the bed and bank of the creck and sinking a pit 20 feet deep on the west side of the creek. During the work a small sluice trough was used to separate grains of transparent feldspar from the claylike material inclosing the feldspar grains. The strata exposed in the bed and banks of the creek at this locality consist of greenish volcanic tuff containing lenses of gravel, the pebbles of which include both igneous and sedimentary rocks. The tuff is a part of the main tuff bed in the upper part of the Woodbine formation. Some persons have thought that a part of the material in the tuff at this locality was derived from peridotite and that consequently the tuff might be diamondbearing. That a very little of it was so derived is likely, but the microscopic study of the tuff by Ross failed to disclose any fragments of peridotite. Prospecting that was done here in 1920 by Captain Dixon is reported by him to have led to the discovery of five small diamonds, which have been presented to the American Museum of Natural History.

Three small diamonds shown to Ross and Miser in 1923 are said by George Power to have been found in that year on his place in sec. 11, T. 9 S., R. 27 W., about 3 miles north of Nashville. (See fig. 17.) Mr. Power says that two of the stones, one a light-yellow stone weighing about a third of a carat and the other a white stone weighing about one-fifth of a carat, were found on the pile of material obtained from digging his well in 1919. The well passed through 14 feet of gravel and then penetrated 36 feet of greenish and gray material without passing through it. This material, although much weathered from four years' exposure on the surface, is apparently volcanic tuff. It was in this apparent volcanic tuff that $\mathrm{Mr}$. Power says he found the two diamonds. A third stone, white with a flattened ricelike shape, was, according to Mr. Power, found by him 100 yards southeast of his house and thus some distance away from the material removed from the well.

\section{DEPOSITS OF KAOLIN (ALTERED VOLCANIC MATERIAL)}

Beds of kaolin occur in the Tokio formation in the hilly, wooded region between Murfreesboro and Delight, Ark. (See pl. 20.) The kaolin, as explained on pages 186 and 187, is probably altered and reworked feldspathic material derived from volcanic ash. It occurs as horizontal layers near the tops of hills at several localities. The greatest thickness observed by the writers is 5 feet, but the greatest reported thickness is 9 feet. The deposits have been prospected, and the kaolin is reported to be a satisfactory fuller's earth for refining edible oils and petroleum. 
One of the best-known occurrences is at the Adams kaolin pits, on land of the Ozan Lumber Co., in the NE. $1 / 4$ SE. $1 / 4$ sec. 24 , T. 8 S., R. 24 W., 5 miles eastsoutheast of Murfreesboro. Here a 5 -foot bed has been opened by three or four cuts on the hill slopes. The kaolin is underlain by a bed of sand fully 32 feet thick and is overlain directly by sand and this sand in turn by gravel. The sand and gravel overburden on one hill is 13 feet thick and on a near-by hill, southwest and west of the first pit, 20 to 25 feet thick. The bed lies horizontal. Apparently not enough prospecting has been done to determine the extent or continuity in thickness of the bed, though the thickness in the two cuts examined by the writers is 5 feet.

The kaolin at the Adams pits is chalky white to creamy, but the lowest layer, a foot thick, has a lavender color. The kaolin is very fine grained, breaks with a conchoidal fracture, and readily absorbs water, sticking tightly to a person's tongue, but it does not become plastic even with fine grinding. It shows laminations along which it splits with some difficulty, and it contains a few fossil leaves, a collection of which was obtained from the two principal openings. The collection has been studied by E. W. Berry and found by him to represent an Upper Cretaceous flora.

A second locality, which is about 1,000 feet eastnortheast of the Adams pits, is in the SE. 1/4 NE. 1/4 sec. 24 , T. 8 S., R. 25 W., on land of the Grayson-McLeod Lumber Co. The locality has been prospected by several pits, but the results are not known except that a 5 -foot bed of kaolin similar to that at the Adams pits was found.

The kaolin on the land of the Ozan Lumber Co. and the Grayson-McLeod Lumber Co. has been tested by commercial firms to determine its value both as a china clay and as a fuller's earth. Test pieces of china made from the clay are said to have been of excellent quality except that the color of the fired china was cream to yellow. Tests are said to show that the kaolin as fuller's earth has proved satisfactory in the refining of both edible oils and petroleum. That the kaolin has the properties of fuller's earth was verified in the chemical laboratory of the United States Geological Survey by testing a sample collected by Miser from the Adams pits.
Thinner deposits of kaolin were examined by the Arkansas Geological Survey some 35 years ago. One of these, containing 2 feet of kaolin the upper foot of which is pink and the lower foot white, occurs in the NW. $1 / 4$ SW. $1 / 4$ sec. 19, T. 8 S., R. 24 W. ${ }^{63}$ Analyses are given below.

Analyses of kaolins from Vaughn Creek, Pike County, Ark. [Dr. T. C. Van Nuys, analyst]

\begin{tabular}{|c|c|c|}
\hline & Upper bed & Lower bed \\
\hline 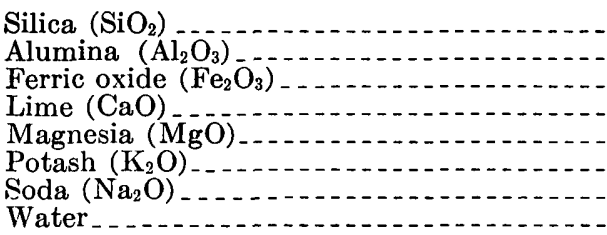 & $\begin{array}{r}48.87 \\
36.51 \\
.98 \\
.19 \\
.25 \\
\hdashline 13.29\end{array}$ & $\begin{array}{r}47.39 \\
34.67 \\
2.31 \\
.32 \\
\text { Trace. } \\
.20 \\
.39 \\
13.89\end{array}$ \\
\hline Water at $110^{\circ}$ to $115^{\circ} \mathrm{C}$ & 100.11 & $\begin{array}{r}97.17 \\
1.00\end{array}$ \\
\hline
\end{tabular}

Other reported deposits in the same vicinity as the three localities described above are briefly described by Branner. Some of the thicknesses reported to members of the Arkansas Geological Survey were as great as 9 feet.

A 5 -foot bed of kaolin like that at the Adams pits was reported by C. W. Adams to lie in a small hill in the SW. $1 / 4 \mathrm{SE} .1 / 4 \mathrm{sec} .24$, T. $8 \mathrm{~S} .$, R. $25 \mathrm{~W}$. The overburden of sand and gravel is said by Mr. Adams to be 15 to 20 feet thick.

A bed of kaolin 23 inches thick was observed by Miser in 1909 in a cut and pit in the NE. 1/4 sec. 29, T. $8 \mathrm{~S}$., R. $24 \mathrm{~W}$. It is pearly white, is free from sand, and does not appear to be plastic. It is closely laminated, and thin films are stained red and yellow along the laminae.

Two pits revealing hard nonplastic kaolin were examined by Miser in 1909 in the southeastern part of sec. 9, T. 8 S., R. 24 W. One of the pits showed 24 inches and the other 28 inches of white kaolin stained with iron oxide along many joints and laminae. The kaolin is underlain by sand and is overlain by sand and gravel that probably attain a thickness of 15 to 20 feet on the top of the hill.

${ }^{63}$ Branner, J. C., The clays of Arkansas: U. S. Geol. Survey Bull. 351, pp. 148-153, 1908. 